\title{
Beyond Dichotomous Approach, Experts Method Compatibles with an Information System View for Developing a Valid Corporate Governance Index
}

\author{
Maysa Ali Abdallah ${ }^{1, *}$ \\ ${ }^{1}$ Department of Accounting, Tanta University, Egypt \\ *Corresponding author: Department of Accounting, Tanta University, PO Box 31521, Tanta- \\ NBE Street, Egypt. Tel: 2-0127-199-8395. E-mail: maysa_ali@commerce.tanat.edu.eg
}

Received: January 14, $2021 \quad$ Accepted: April 16, $2021 \quad$ Published: May 7, 2021

doi: 10.5296/jcgr.v5i1.18208 URL: https://doi.org/10.5296/jcgr.v5i1.18208

\begin{abstract}
This paper provides a critical review of the corporate governance quantification process at academic and professional levels to scrutinize the main troubles in the black box of CG assessment models and spot some lights on how to develop a valid Corporate Governance Index (CGI) at the firm and industry levels regarding evenly the entire stakeholders' perceptions. Prior literature has been reviewed and a Corporate Governance index was constructed merging the power of multi-methodologies: Principal Component Analysis (PCA), Delphi Technique and Stability analysis. The findings show that the validity of the results necessitates enforcing End to End processes and taking into account the country's individualization to increase the reliability and comparability of the results. As well, the governance ratings are sensitive to the applied methodology, particularly, a well-known approach in quantifying CG, i.e., dichotomous approach, is underestimated the index findings then it will directly affect all aspects of governance endogeneity with firm's performance/value. This research has important practical implications for governance guidelines setters, companies, stakeholders and other researchers. For the G setters, it underlines the necessity to make harmonization between industries' regulations and governance code, and revise the priority of the "comply or explain" approach in practice; which could serve as a roadmap for future improvements and researches. For companies, this paper highlights which effective $G$ mechanisms and urges the role of the boardroom in monitoring and explanations for non-compliance. For CGI users, the research highlights that ratings' users should be more precautions and concerned about the base of the assessing models.
\end{abstract}

Keywords: corporate governance index, information system view, Principal Component Analysis, Delphi technique, stability analysis, dichotomous approach 


\section{Introduction}

Sound good governance concept has given, recently, higher priority in the country's development plans for boosting investors' confidence, business integrity and improving access to capital markets (Agyemang et al., 2019, p. 1134). Through coming up with reforms in corporate governance structure, numbers of regulations as a guide of best practices of corporate governance have been introduced; such as Sarbanes Oxley act of 2002 in the USA, Higgs report by 2003 in the UK (Abdullah and Page, 2009, p.7; Pletz \& Upson, 2019, P. 1027), also the Australian stock market had issued good governance principles as a benchmark of good practices in corporate governance by 2003 (Linden and Matolcsy, 2004, p. 9).

The initiative of launching a corporate governance code was taken up comparatively late in Germany; the first code of best practice, developed by the Policy Commission Corporate Governance in 2000 (Rühmkorf et al., 2019, p. 1047). Indeed, the Intergovernmental Working Group of Experts on International Standards of Accounting and Reporting (ISAR) has undertaken several actions in terms of Assisting developing countries and transition economies to strengthen their regulatory in order to enhance corporate transparency and accountability, they issued a Guidance of Good Practices in Disclosure as a benchmark of good corporate governance (UNCTAD, 2006).

Developing countries in line with the global trends have encouraged companies to cope with the best practices of corporate governance for monitoring management and minimizing conflicts of interest among principal-agent and principal-principal (Sabbaghi, 2016, p. 868; Kao et al., 2019, p. 738; Crisóstomo \& de Freitas Brandão, 2019, P.121), Taiwan financial Supervisory Commission, for instance, set their own Roadmap for 2018-2020 intends to boost active participation of all parties in corporate governance to assist corporate governance culture entrenched, generate an investment-friendly environment and advance companies' global affordability (Financial Supervisory Commission, 2018, p. 3).

From another perspective, international rating agencies have intended to quantify governance practices through developing commercial scoring systems in order to rank companies in terms of their governance practices. For instance, Institutional shareholder services (ISS) launched a Corporate Governance Quotient (CGQ, 2002) and the Corporate Governance quick Score (CGS, 2013) (ISS, 2013) for helping institutional investors to avoid high-risk investment opportunities (Khanchel, 2007), where high rating corporations are more attractive for investors rather than low rating corporations (Mallin, 2003, p. 77; Grimminger \& Benedetta, 2013, p1).

Consequently, academic researchers have increasingly run on building individual quantitative models such as GOV- index designed by Klapper and Love (2002), G-index by Gompers et al. (2003) and GOV index for Aggarwal et al. (2007) to name just a few, to test the endogeneity problem of corporate governance mechanisms through clarifying the relationship between corporate governance quality and the firm performance. Despite the intensive efforts in dealing with threats of risks, the dropping of the UK's Carillion company in January 2018 spotting the world light on the rethinking of the activation role of corporate governance 
mechanisms (Goergen et al., 2010, p. 58; OECD Report, 2015, p. 3) to act in adherence to the ethical code not merely in compliance with governance rules (Fathi, 2013, p. 3), which can be regarded as a trigger factor for the firm's reputation and integrity (Arjoon, 2006, p. 35).

Beyond different factors of Carillon going bankrupt, the researchers revealed that Carillion buckled under reasons are merely focused on the company's governance structure and its effectiveness on governed the company. Stakeholders have started to question the enforcement of the board of directors and its committees in nominating and compensating the formal executive and non-executive members, and whether the company's boardroom invested in its power to conduct ethically and managing risks mitigating the costs of poor governance (Pratley, 2018; McCulloch, 2018).

But the governance evaluating methodologies failed to test if the company governed ethically because it's merely focused on the existence of monitoring mechanisms, not on the effectiveness of such mechanisms. As it's narrowing the scope of good governance in just respecting a set of regulations, but sound good governance is an organizational culture that manages and regulates the company's internal and external relations and oversight the company effectively (Egyptian Institute of directors (EIOD), 2016).

Undoubtedly, the majority of governance quantification studies do not consider the criterion of validity \& reliability. So, it necessitates rethinking of the evaluating methodologies of companies' governance practices; the wider the scope of governance of achieving accountability, transparency, and business integrity, the greater the tangible benefits will be for all related parties.

In this sense, the current study aims at shedding some light on how to construct a valid CG index, considering how the scholars and practitioners approached their prioritization process and enrich the knowledge about the role of experts' views and country individualization at different stages of the assessment model. This study contributes to the corporate governance literature in several ways. First, this study provides advanced initiatives on CG ratings in terms of information system, as far as the researcher knowledge this is the first attempt contributes to study the construction and implementation of governance assessment index regarding information system concepts.

Second, dissimilar with a large amount of the previous literature (Shabbir \& Badgett, 2005; Beiner et al., 2006; Haldar \& Rao, 2013, Tariq \& Abbas, 2013; Black et al., 2017), this study overcomes the lacking of theory to build a composite index derived from national and international corporate governance benchmark using Expert's methods, statistical analysis and stakeholders' perceptions. Third, while several studies used a dichotomous/binary approach (La porta et al., 1998; Gompers et al., 2003); Drobetz et al., 2004; Brown \& Caylor, 2006; Arcot \& Bruno, 2007; Clacher et al., 2008; Price et al.; 2011) this study assigns different weights for different components using experts' method regarding the deviation on the relative importance of index components and to avoid subjectivity. Fourth, the current study addresses the value to all stakeholders rather than shareholders and bond-holders.

The rest of this paper is organized in three main sections as follows: section 2 narrates the 
governance assessment models in the relevant literature, Section 3 states the Theoretical Framework for building the CGI involving the problematic issues related to the construction phase and the proposed solutions regarding to information system view in three sub-sections. The application phase outlines in Section 4, and Section 5 reports the research conclusions and recommendations.

\section{Literature Review}

Academics and practitioners are in progress to provide and use a quantitative metric that rate companies' governance practices since 1998-1999 when La Porta et al. (1998) and Brunswick UBS Warburg investment bank introduce two different indices - Anti Director Rights index and CG index, respectively- to identify to what extent laws are caring the investor rights in 39 countries (La Porta et al., 1998) for the first index and evaluating the governance structure as a whole for 21 Russian companies from 1999 to 2000 (Rutherford and Costello report, 1999) for the second one.

In the light of the extensive reviewing of commercial governance scoring literature by Daines et al. (2009) and academic scoring models by Nerantzidis (2018); there is no a verifiable and satisfactory formulated of quantifying the governance quality, however, all attempts to quantifying governance aspects seem to agree upon the target (Daines et al., 2009, P.19), There is an ongoing debate on how to assess the firm's governance performance and criticizes the methodological challenges of this procedure (Bhagat et al., 2008; Bozec \& Bozec, 2011; Aguilera \& Desender, 2012; Nerantzidis, 2016).

In their governance quantifying papers, Moody's rating (2002); Balling et al. (2005); Schnyder (2012); Baldacchino et al. (2015); Nerantzidis (2016); Hitz \& Lehmann (2015) acknowledged that rating methodology should meet two main bases. First, the main relevant aspects of corporate governance should be built in the scoring model, second, the procedures to be followed in prioritizing the quality of firms' governance performance. In this respect, matrix 1 summarizes the multi-methodologies applied by academic developers, commercial rating vendors, and professional institutions \& stock exchanges in constructing CG assessing models to spell out the problematic issues involved in the construction phase.

The three main sections of Matrix 1, revealed the main steps of building the conceptual framework of CG quantitative models and the implications of such frameworks compared among three main groups of constructors; the researchers; the credit rating agencies and the professional institutions \& stock markets. Starting with the first part of the governance scoring methodology in column 4 (entitled benchmark), numbers of accrediting national and international CG benchmarks have been used to evaluate the firms' governance practices. However, international best practices of good governance -OECD principle 1999 revised 2004 and IRRC governance attributes- are common in 3 governance quantitative models.

The focal benchmark followed by researchers and professional institutions is the national governance codes of firms' countries investigated, by 7 models on average, where the combination of national and international governance codes is mostly the domain of 
commercial governance models; for three indices used a variety of governance sources. Also, corporate laws, commercial models and even governance literature were followed as a basis for two models to capture their components.

As can be observed in column 5, professional and commercial ratings are used a large set of governance measures compared to academics, by 60 to 24.13 variables on average. Such measures are categorized under different dimensions; just about 4.75, 6, 5.25 pillars are used on average in panel one, two and three respectively. These rooms for diversity in the selection of multitude governance pillars and the criterion can be better understood by means of the lack of theory to ideal the extraction of relevant encompassing governance attributes.

Another disturbance of lacking theory could be the weighting approach, there are conflicting views on how to weighting the extracted governance factors; academics devoted equal weights to all criteria using a dichotomous approach, 6 Non-weighting indexes compared to 2 weighting indexes to avoid subjectivity in measurement and arbitrary weights. Nevertheless, the Equal weights approach has minor significance in practice compared to the weighting approach, where the first one was followed in 2:1 model. Commercial and professional rating providers are reliant on their expertise to assign different weights with concealing on their functional techniques ( 8 to 3 models respectively) with a lack of disclosure about how to determine such weights.

Correspondingly, the academic scoring models are apparent to be criticized in ranking companies based upon simple summing up of binary attributes through analyzing annual reports and filing a checklist of disclosed or not disclosed governance items without the reasoning of equal weights (Strenger, 2004, p.13, Florou \& Galarniotis, 2007, p.984; Schnyder, 2012, p.9). Yet, the grades of calculation based on simply summing up different dimensions and just analyzing the existence or not the existence of $G$ dimensions; underestimated the firms' governance value and failed to identify areas of deficiencies in firms' governance structure and hence areas of improvement (Al-Shiab, 2003, p.222).

To sum up, the great effort was and still to measure the commitment of the best practices of corporate governance ensures the essential role of good governance in motivating business confidence and integrity. However, different scoring models have many similarities specifically their target; concerns arose about construct validity and reliability of such systems. Given the aforementioned methodologies, the variations in the prioritization process are exhibiting the distinction on countries' cultures, regulations, capital markets' efficiency, basis of governance compliances; mandatory or voluntarily.

Those variations stimulate the differentiation on the stock market and stakeholders' requirements; which well-thought-out according to S\&P's (2004) as a motivation behind launching a specific governance assessment model for each country, which suited with Arcot \& Bruno (2005), Coles et al. (2008), Munisi \& Randøy (2013) argument that "one system does not fit all". But which variables could be selected? Whether governance components are equally significant or some are weighty than others? Whether the prioritization process intents to evaluate almost the existence of governance tools or valuing work effectiveness? 


\section{Macrothink}

Journal of Corporate Governance Research

ISSN 1948-4658

2021, Vol. 5, No. 1

Table 1. Analysing of the Academic, Commercial and Professional CG Quantitative Models

\begin{tabular}{|c|c|c|c|c|c|c|c|}
\hline \multirow{2}{*}{$\begin{array}{l}\text { Governance } \\
\text { Scoring } \\
\text { providers }\end{array}$} & \multirow{2}{*}{$\begin{array}{c}\mathrm{G} \\
\text { Model }\end{array}$} & \multicolumn{3}{|c|}{ Practical Methodology } & \multirow{2}{*}{$\begin{array}{l}\text { Index } \\
\text { type }\end{array}$} & \multirow{2}{*}{$\begin{array}{c}\text { Sources of } \\
\text { Data }\end{array}$} & \multirow{2}{*}{$\begin{array}{c}\text { No. of } \\
\text { spotlight } \\
\text { Companies }\end{array}$} \\
\hline & & Benchmark & Pillars of CG & $\begin{array}{l}\text { Weighting } \\
\text { scheme }\end{array}$ & & & \\
\hline \multicolumn{8}{|c|}{ Panel 1, Academic providers } \\
\hline $\begin{array}{l}\text { La porta et al. } \\
\text { (LLSV, 1998) }\end{array}$ & $\begin{array}{l}\text { Anti-D } \\
\text { irector } \\
\text { Rights }\end{array}$ & $\begin{array}{c}\text { G rules in } \\
39 \\
\text { countries }\end{array}$ & $\begin{array}{l}\text { Shareholders' } \\
\text { rights attribute } \\
\text { measured by } 6 \\
\text { sub-criteria }\end{array}$ & $\begin{array}{c}\text { Equal } \\
\text { weights } \\
{[(0,1)} \\
\text { approach }]\end{array}$ & $\begin{array}{l}\text { Scorin } \\
\mathrm{g} \text { from } \\
0 \text { to } 6 \\
\text { points }\end{array}$ & $\begin{array}{l}\text { annual } \\
\text { reports }\end{array}$ & $\begin{array}{c}\text { Listed firms } \\
\text { in } 39 \\
\text { countries }\end{array}$ \\
\hline $\begin{array}{c}\text { Bujaki \& } \\
\text { McConomy } \\
\text { (2002) }\end{array}$ & $\begin{array}{l}\text { Volunt } \\
\text { ary } \\
\text { Disclos } \\
\text { ure } \\
\text { Index }\end{array}$ & $\begin{array}{l}\text { Toronto } \\
\text { Stock } \\
\text { Exchange } \\
\text { guidelines } \\
\text { on CG. }\end{array}$ & $\begin{array}{l}25 \text { measures } \\
\text { covered } 14 \\
\text { guidelines } \\
\text { related to board } \\
\text { of directors, } \\
\text { board } \\
\text { committees and } \\
\text { disclosure. }\end{array}$ & $\begin{array}{c}\text { dichotomou } \\
\text { s scoring } \\
\text { system } \\
{[(0,1)} \\
\text { approach }]\end{array}$ & $\begin{array}{l}\text { Scorin } \\
\mathrm{g} \text { from } \\
0 \text { to } 25 \\
\text { points }\end{array}$ & $\begin{array}{c}290 \text { annual } \\
\text { reports in } \\
1997\end{array}$ & $\begin{array}{l}\text { 272Canadian } \\
\text { firms listed } \\
\text { in TSE } 300 \\
\text { index }\end{array}$ \\
\hline $\begin{array}{l}\text { Gompers et al. } \\
\text { (GIM, 2003) }\end{array}$ & $\begin{array}{c}\text { G- } \\
\text { Index, } \\
\text { or } \\
\text { Anti-T } \\
\text { akeove } \\
\text { r Index }\end{array}$ & $\begin{array}{c}\text { International } \\
\text { Responsibili } \\
\text { ty Research } \\
\text { Center G } \\
\text { measures }\end{array}$ & $\begin{array}{c}24 \text { measures } \\
\text { listed in five } \\
\text { categories: } \\
\text { tactics for } \\
\text { delaying hostile } \\
\text { bidders; voting } \\
\text { rights; } \\
\text { director/officer; } \\
\text { other takeover } \\
\text { defenses; and } \\
\text { state laws. }\end{array}$ & $\begin{array}{c}\text { Equal } \\
\text { weights } \\
{[(0,1)} \\
\text { approach }]\end{array}$ & $\begin{array}{l}\text { Scorin } \\
\mathrm{g} \text { from } \\
0 \text { to } 24 \\
\text { points }\end{array}$ & $\begin{array}{c}\text { Public } \\
\text { Information } \\
\text { from } \\
\text { 1990-1999 }\end{array}$ & $\begin{array}{c}1500 \text { US } \\
\text { listed } \\
\text { companies }\end{array}$ \\
\hline $\begin{array}{l}\text { Drobetz et al., } \\
2004\end{array}$ & $\begin{array}{c}\text { Good } \\
\text { CG } \\
(\mathrm{GCG})\end{array}$ & $\begin{array}{c}\text { German } \mathrm{CG} \\
\text { Code }\end{array}$ & $\begin{array}{c}5 \text { provisions } \\
\text { measured using } \\
30 \text { variables } \\
\text { covering: board } \\
\text { role, } \\
\text { Shareholders } \\
\text { rights, } \\
\text { disclosure and } \\
\text { control. }\end{array}$ & $\begin{array}{c}\text { Equal } \\
\text { weights } \\
{[(0,1)} \\
\text { approach }]\end{array}$ & $\begin{array}{l}\text { Scorin } \\
\mathrm{g} \text { from } \\
0 \text { to } 30 \\
\text { points }\end{array}$ & $\begin{array}{l}\text { Questionnai } \\
\text { re + annual } \\
\text { reports from } \\
1998-2002 .\end{array}$ & $\begin{array}{l}91 \text { German } \\
\text { companies }\end{array}$ \\
\hline $\begin{array}{c}\text { Tsipouri \& } \\
\text { Xanthakis, } 2004\end{array}$ & CGI & $\begin{array}{l}\text { Blue book } \\
\text { (revision of } \\
\text { OECD), } \\
1999\end{array}$ & $\begin{array}{c}37 \text { variables } \\
\text { covered } 5 \\
\text { attributes: } \\
\text { Shareholders } \\
\text { rights and } \\
\text { responsibilities, } \\
\text { transparency \& } \\
\text { disclosure, } \\
\text { auditing, board } \\
\text { of directors and } \\
\text { governance } \\
\text { compliance. }\end{array}$ & $\begin{array}{l}\text { Weighting } \\
\text { approach } \\
\text { using Expert } \\
\text { method }\end{array}$ & $\begin{array}{l}\text { Scorin } \\
\mathrm{g} \text { from } \\
0 \text { to } \\
100\end{array}$ & $\begin{array}{l}\text { Checklist } \\
\text { filing from } \\
\text { annual } \\
\text { reports }\end{array}$ & $\begin{array}{l}120 \text { Greek } \\
\text { companies }\end{array}$ \\
\hline
\end{tabular}




\begin{tabular}{|c|c|c|c|c|c|c|c|}
\hline Price et al., 2011 & CGI & $\begin{array}{l}\text { Mexico's } \\
\text { Code of } \\
\text { Best } \\
\text { Corporate } \\
\text { Practices }\end{array}$ & $\begin{array}{l}55 \text { internal } \\
\text { governance } \\
\text { mechanisms } \\
\text { used to measure } \\
3 \text { main criteria: } \\
\text { board structure; } \\
\text { internal control } \\
\text { and disclosure }\end{array}$ & $\begin{array}{c}{[(0,1)} \\
\text { approach }]\end{array}$ & $\begin{array}{l}\text { Percent } \\
\text { ile } \\
\text { index } \\
(0-100 \\
\%)\end{array}$ & $\begin{array}{l}\text { Questionnai } \\
\text { re filling } \\
\text { from annual } \\
\text { reports } \\
(2000-2004)\end{array}$ & $\begin{array}{l}107 \text { firms } \\
\text { listed in } \\
\text { Mexico } \\
\text { Stock } \\
\text { Exchange }\end{array}$ \\
\hline $\begin{array}{l}\text { Gordon et al., } \\
2012\end{array}$ & CGI & $\begin{array}{l}\text { G Guideline } \\
\text { of Toronto } \\
\text { Stock } \\
\text { Exchange } \\
\text { (TSX) }\end{array}$ & $\begin{array}{c}14 \text { TSX } \\
\text { corporate } \\
\text { governance } \\
\text { guidelines } \\
\text { measuring by } 22 \\
\text { dimensions }\end{array}$ & $\begin{array}{c}(0,1) \\
\text { approach }\end{array}$ & $\begin{array}{l}\text { Scorin } \\
\mathrm{g} \text { from } \\
(0 \text { to } \\
22)\end{array}$ & $\begin{array}{l}\text { proxy data } \\
\text { collected } \\
\text { for the TSX } \\
\text { companies }\end{array}$ & $\begin{array}{c}1,617 \\
\text { companies } \\
\text { traded on } \\
\text { TSX }\end{array}$ \\
\hline $\begin{array}{l}\text { Nerantzidis, } \\
2016\end{array}$ & $\begin{array}{l}\text { Transp } \\
\text { arent, } \\
\text { reliable } \\
\& \\
\text { valid } \\
\text { CG } \\
\text { index }\end{array}$ & $\begin{array}{l}\text { Greek laws } \\
\text { for CG, } \\
\text { SEV \& } \\
\text { combined } \\
\text { code. }\end{array}$ & $\begin{array}{c}79 \text { variables } \\
\text { used to quantify } \\
5 \text { main pillars of } \\
\text { Greece firms G } \\
\text { practices; board } \\
\text { and its member; } \\
\text { internal control; } \\
\text { shareholders } \\
\text { relation \& } \\
\text { communication; } \\
\text { information } \\
\text { disclosure and } \\
\text { board } \\
\text { remuneration }\end{array}$ & $\begin{array}{l}\text { Un equal } \\
\text { weights } \\
\text { assigned } \\
\text { using the } \\
\text { AHP } \\
\text { approach }\end{array}$ & $\begin{array}{l}\text { Firms } \\
\text { evaluat } \\
\text { ing } \\
\text { from }(0 \\
\text { to } 100)\end{array}$ & $\begin{array}{c}\text { Public } \\
\text { information }\end{array}$ & $\begin{array}{l}219 \text { firms in } \\
\text { Athens } \\
\text { Stock } \\
\text { Exchange } \\
\text { (ASE) } \\
\text { (Continued) }\end{array}$ \\
\hline Matrix 1: & & & & & & & \\
\hline $\begin{array}{l}\text { Governance } \\
\text { Scoring } \\
\text { providers }\end{array}$ & $\begin{array}{c}\mathrm{G} \\
\text { Model }\end{array}$ & Benchmark & $\begin{array}{l}\text { actical Methodolo } \\
\text { Pillars of CG }\end{array}$ & $\begin{array}{l}\text { Weighting } \\
\text { scheme }\end{array}$ & $\begin{array}{l}\text { Index } \\
\text { type }\end{array}$ & $\begin{array}{l}\text { Sources of } \\
\text { Data }\end{array}$ & $\begin{array}{c}\text { No. of } \\
\text { spotlight } \\
\text { Companies }\end{array}$ \\
\hline \multicolumn{8}{|c|}{ Panel 2. Commercial Vendors } \\
\hline $\begin{array}{c}\text { Brunswick } \\
\text { (UBS) Warburg, } \\
1999\end{array}$ & $\begin{array}{c}\mathrm{G} \\
\text { Score } \\
\text { Index }\end{array}$ & $\mathrm{N}$ & $\begin{array}{l}17 \text { measures } \\
\text { divided into } 8 \\
\text { governance } \\
\text { pillars: } \\
\text { transparency, } \\
\text { share dilution } \\
\text { risk, asset } \\
\text { transfer and } \\
\text { transfer pricing } \\
\text { risk, merger and } \\
\text { restructuring } \\
\text { risk, bankruptcy } \\
\text { risk, ownership } \\
\text { restrictions, } \\
\text { corporate } \\
\text { governance } \\
\text { initiatives, and } \\
\text { registrar risk. }\end{array}$ & $\begin{array}{l}\text { Different } \\
\text { weights } \\
\text { with } \\
\text { Non-disclos } \\
\text { ure about } \\
\text { their } \\
\text { approach }\end{array}$ & $\begin{array}{l}\text { overall } \\
\text { govern } \\
\text { ance } \\
\text { score } \\
\text { of } 60 \\
\text { points }\end{array}$ & $\begin{array}{c}\text { Public } \\
\text { information } \\
\text { from } \\
\text { financial } \\
\text { reports }\end{array}$ & $\begin{array}{l}21 \text { listed } \\
\text { firms from } \\
1999-2003\end{array}$ \\
\hline
\end{tabular}




\begin{tabular}{|c|c|c|c|c|c|c|c|}
\hline $\begin{array}{c}\text { Standard \& } \\
\text { Poor's (S\&P's, } \\
\text { 2002) }\end{array}$ & T\&D & $\begin{array}{c}\text { Different } \\
\text { sources of } \\
\text { governance } \\
\text { best } \\
\text { practices }\end{array}$ & $\begin{array}{c}98 \text { questions } \\
\text { covering } 3 \text { main } \\
\text { governance } \\
\text { attributes; } \\
\text { ownership } \\
\text { structure and } \\
\text { investors' rights, } \\
\text { transparency \& } \\
\text { disclosure and } \\
\text { board and } \\
\text { executive } \\
\text { management } \\
\text { structure and } \\
\text { operations }\end{array}$ & $\begin{array}{c}\text { Equal } \\
\text { weights } \\
{[(0,1)} \\
\text { approach] }\end{array}$ & $\begin{array}{c}\text { Percent } \\
\text { ile } \\
\text { index } \\
(0-100 \\
\%)\end{array}$ & $\begin{array}{l}\text { Checklist } \\
\text { from public } \\
\text { information }\end{array}$ & $\begin{array}{c}1500 \\
\text { companies } \\
\text { listed in } \\
\text { S\&P's } \\
\text { Global } 1200 \\
\text { \&300 in } \\
\text { S\&P/IFCI }\end{array}$ \\
\hline $\begin{array}{c}\text { Standard \& } \\
\text { Poor's (S\&P's, } \\
\text { 2002) }\end{array}$ & CGS-I & $\begin{array}{c}\text { OECD, } \\
1999+ \\
\text { world bank } \\
\text { guidelines + } \\
\text { other } \\
\text { resources }\end{array}$ & $\begin{array}{c}80 \text { procedures } \\
\text { classed under } \\
\text { four } \\
\text { components; } \\
\text { ownership } \\
\text { structure and } \\
\text { external } \\
\text { influences, } \\
\text { shareholder } \\
\text { rights and } \\
\text { stakeholder } \\
\text { relations, } \\
\text { transparency \& } \\
\text { disclosure and } \\
\text { audit, and board } \\
\text { structure and } \\
\text { effectiveness }\end{array}$ & $\mathrm{N}$ & $\begin{array}{l}\text { Firms } \\
\text { overall } \\
\text { score } \\
\text { arrangi } \\
\text { ng } \\
\text { from } 0 \\
\text { to } 10\end{array}$ & $\begin{array}{l}\text { Checklist } \\
\text { from public } \\
\text { information }\end{array}$ & $\begin{array}{l}\text { depending } \\
\text { on firm } \\
\text { demand with } \\
\text { fees and } \\
\text { without } \\
\text { disclosing of } \\
\text { results }\end{array}$ \\
\hline Moody's, 2002 & $\begin{array}{l}\text { CGA } \\
\text { Index }\end{array}$ & $\begin{array}{c}\text { American } \\
\text { and } \\
\text { Canadian } \\
\text { sources of } \\
\text { governance } \\
\text { rules }\end{array}$ & $\begin{array}{l}20 \text { measures } \\
\text { classify into } 7 \\
\text { pillars include } \\
\text { board of } \\
\text { directors, audit } \\
\text { committee, } \\
\text { conflict of } \\
\text { interest, } \\
\text { compensation } \\
\text { policies, } \\
\text { shareholders } \\
\text { rights, } \\
\text { ownership } \\
\text { structure and } \\
\text { transparency. }\end{array}$ & $\mathrm{N}$ & $\begin{array}{c}\text { Non } \\
\text { disclos } \\
\text { ed }\end{array}$ & $\begin{array}{l}\text { Annual } \\
\text { reports, } \\
\text { SEC } \\
\text { governance } \\
\text { filings and } \\
\text { companies' } \\
\text { websites }\end{array}$ & $\begin{array}{c}\text { USA \& } \\
\text { Canadian } \\
\text { firms }\end{array}$ \\
\hline
\end{tabular}




\begin{tabular}{|c|c|c|c|c|c|c|c|}
\hline $\begin{array}{l}\text { Credit Lyonnais } \\
\text { Securities Asia } \\
\text { (CLSA), } 2001\end{array}$ & $\begin{array}{c}\text { CLSA } \\
\text { CGI }\end{array}$ & $\begin{array}{l}\text { Different } \\
\text { sources of } \\
\text { governance } \\
\text { rules for } \\
\text { Asian } \\
\text { countries }\end{array}$ & $\begin{array}{l}7 \text { provisions of } \\
\text { governance } \\
\text { include } \\
\text { disclosure \& } \\
\text { transparency, } \\
\text { board of } \\
\text { directors' } \\
\text { independence, } \\
\text { responsibilities } \\
\text { and } \\
\text { accountability, } \\
\text { equal treatment } \\
\text { of shareholders, } \\
\text { Environmental } \\
\text { awareness and } \\
\text { financial } \\
\text { discipline } \\
\text { measured by } 57 \\
\text { sub criterions }\end{array}$ & $\begin{array}{c}\text { equal } \\
\text { weights }\end{array}$ & $\begin{array}{l}\text { Percent } \\
\text { ile } \\
\text { from }(0 \\
\text { to } \\
100 \%)\end{array}$ & $\begin{array}{c}\text { Yes-No } \\
\text { questionnair } \\
\mathrm{e}\end{array}$ & $\begin{array}{l}25 \text { emerging } \\
\text { markets }\end{array}$ \\
\hline
\end{tabular}

\begin{tabular}{|c|c|c|c|c|c|c|c|}
\hline \multirow{2}{*}{$\begin{array}{l}\text { Governance } \\
\text { Scoring } \\
\text { providers }\end{array}$} & \multirow{2}{*}{$\begin{array}{c}\mathrm{G} \\
\text { Model }\end{array}$} & \multicolumn{3}{|c|}{ Practical Methodology } & \multirow{2}{*}{$\begin{array}{c}\text { Index } \\
\text { type }\end{array}$} & \multirow{2}{*}{$\begin{array}{c}\text { Sources of } \\
\text { Data }\end{array}$} & \multirow{2}{*}{$\begin{array}{c}\text { No. of } \\
\text { spotlight } \\
\text { Companies }\end{array}$} \\
\hline & & Benchmark & Pillars of CG & $\begin{array}{l}\text { Weighting } \\
\text { scheme }\end{array}$ & & & \\
\hline $\begin{array}{c}\text { Japan Corporate } \\
\text { Governance } \\
\text { Research } \\
\text { (JCGR, 2005) }\end{array}$ & JCGR & $\begin{array}{c}\text { governance } \\
\text { regulations } \\
\text { in Japan }\end{array}$ & $\begin{array}{c}8 \text { pillars covered } \\
\text { board structure } \\
\& \\
\text { compensation, } \\
\text { charter by law } \\
\text { provisions, audit } \\
\text { issues, } \\
\text { anti-takeovers } \\
\text { practices, } \\
\text { executives \& } \\
\text { directors' } \\
\text { compensation, } \\
\text { board } \\
\text { performance } \\
\text { review, stock } \\
\text { ownership and } \\
\text { director's } \\
\text { education }\end{array}$ & $\begin{array}{l}\text { Un -equal } \\
\text { weights } \\
\text { without, } \\
\text { disclosure } \\
\text { about their } \\
\text { method }\end{array}$ & $\begin{array}{c}\text { Percent } \\
\text { ile } \\
\text { ranging } \\
\text { from (0 } \\
\text { to } \\
100 \%)\end{array}$ & Survey & $\begin{array}{c}\text { Listed } \\
\text { companies } \\
\text { in Tokyo } \\
\text { stock } \\
\text { exchange }\end{array}$ \\
\hline
\end{tabular}




\begin{tabular}{|c|c|c|c|c|c|c|c|}
\hline ISS, FTSE, 2005 & $\begin{array}{l}\text { FTSE } \\
\text { ISS } \\
\text { CGI }\end{array}$ & $\begin{array}{l}\text { Governance } \\
\text { regulations } \\
\text { in developed } \\
\text { countries }\end{array}$ & $\begin{array}{l}61 \text { measures for } \\
5 \text { main criteria; } \\
\text { compensation } \\
\text { system, stock } \\
\text { ownership by } \\
\text { executives and } \\
\text { non-executives } \\
\text { board members, } \\
\text { ownership } \\
\text { structure, audit } \\
\text { integrity, board } \\
\text { of directors' } \\
\text { structure and } \\
\text { independence. }\end{array}$ & $\mathrm{N}$ & $\begin{array}{l}\text { Scorin } \\
\text { g from } \\
1 \text { to } 5 .\end{array}$ & $\begin{array}{l}\text { Governance } \\
\text { data } \\
\text { provided by } \\
\text { ISS }\end{array}$ & $\begin{array}{l}2200 \text { firms } \\
\text { in } 24 \\
\text { developed } \\
\text { countries }\end{array}$ \\
\hline \multicolumn{8}{|c|}{ Panel 3. Professional Institution \& Stock Markets } \\
\hline $\begin{array}{l}\text { Indonesian } \\
\text { Institute for } \\
\text { Corporate } \\
\text { Governance, } \\
2005\end{array}$ & $\begin{array}{l}\text { Corpor } \\
\text { ate } \\
\text { Govern } \\
\text { ance } \\
\text { Percept } \\
\text { ion } \\
\text { Index } \\
\text { (CGPI) }\end{array}$ & $\begin{array}{l}\text { Indonesian } \\
\text { governance } \\
\text { guidelines }\end{array}$ & $\begin{array}{l}5 \text { main pillars } \\
\text { include } \\
\text { Shareholders } \\
\text { rights \& } \\
\text { ownership } \\
\text { functions, equal } \\
\text { treatment of } \\
\text { shareholders, } \\
\text { board of } \\
\text { directors' } \\
\text { responsibilities, } \\
\text { transparency \& } \\
\text { disclosure and } \\
\text { stakeholders' } \\
\text { role in } \\
\text { governance. }\end{array}$ & $\mathrm{N}$ & - & $\begin{array}{c}\mathbf{1}^{\text {st }} \text { stage: } \\
\text { questionnair } \\
\text { e } \\
\mathbf{2}^{\text {nd }} \text { stage: G } \\
\text { documentati } \\
\text { ons } \\
\mathbf{3}^{\text {rd }} \text { stage: } \\
\text { written } \\
\text { explanation }\end{array}$ & $\begin{array}{c}\text { Listed } \\
\text { Indonesian } \\
\text { companies }\end{array}$ \\
\hline $\begin{array}{c}\text { S\&P'S \& } \\
\text { Institute for CG } \\
\text { (Hawk amah), } \\
2011\end{array}$ & $\begin{array}{c}\text { Enviro } \\
\text { nment, } \\
\text { Social } \\
\text { and } \\
\text { Govern } \\
\text { ance } \\
\text { (ESG) } \\
\text { Index }\end{array}$ & $\begin{array}{l}\text { governance } \\
\text { rules for the } \\
\text { middle east } \\
\text { and south } \\
\text { Africa }\end{array}$ & $\begin{array}{l}7 \text { provisions } \\
\text { covered } \\
\text { shareholders } \\
\text { rights, board of } \\
\text { directors, } \\
\text { disclosure \& } \\
\text { transparency, } \\
\text { auditing/internal } \\
\text { control, } \\
\text { ownership } \\
\text { concentration. } \\
\text { work ethics and } \\
\text { management } \\
\text { system }\end{array}$ & $\mathrm{N}$ & $(1-5)$ & $\begin{array}{c}\text { Public } \\
\text { information: } \\
\text { Websites, } \\
\text { newspaper } \\
\text { \& CSR } \\
\text { fillings }\end{array}$ & $\begin{array}{c}150 \text { listed } \\
\text { companies } \\
\text { in } 11 \text { Arab } \\
\text { and African } \\
\text { countries }\end{array}$ \\
\hline $\begin{array}{l}\text { SAGIA, } 2014 \\
\text { (Schwab \& } \\
\text { Sala-i-Martin } \\
\text { 2014) }\end{array}$ & SCGI & $\begin{array}{l}\text { International } \\
\text { G standards } \\
\text { and Saudi } \\
\text { governance } \\
\text { rules }\end{array}$ & $\begin{array}{l}4 \text { attributes: } \\
\text { shareholders } \\
\text { rights, board of } \\
\text { directors \& } \\
\text { committees, } \\
\text { transparency \& } \\
\text { disclosure and } \\
\text { internal } \\
\text { control/risk } \\
\text { management }\end{array}$ & $\begin{array}{c}\text { equal } \\
\text { weights }\end{array}$ & $\begin{array}{c}(0-100 \\
\%)\end{array}$ & $\begin{array}{c}\text { Public } \\
\text { information }\end{array}$ & $\begin{array}{c}\text { Listed } \\
\text { companies } \\
\text { in Tadawul } \\
\text { stock } \\
\text { exchange }\end{array}$ \\
\hline
\end{tabular}


UK IOD \& Good UK code + CQI, Cass business school, 2016

\section{GI \\ corporation} law, 2006

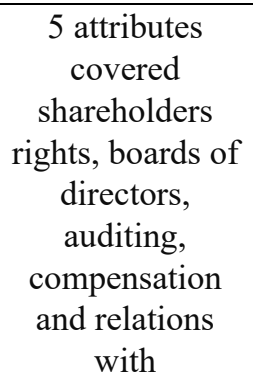

\footnotetext{
$* \mathrm{~N}=$ Non-disclosure available
}

Such questions are the reference point of the proposed typology on building a valid corporate governance index, this study differs from the previous, as it takes into account the countries individualization and the proper measurement theory to offer a valid index from the perspective of both academics and practitioners.

\section{Theoretical Framework for CGI Construction}

As mentioned earlier, there is a theoretical gap in different stages of the index construction; among the components, the weights, technique and rationale. These gaps sustain using different methodologies for different stages to building a valid CGI from the academics and practitioners' perspectives. Despite the fact that costs and benefits of variability in constructing methodologies, be affected by the model's objectives and scope, the degree of embracing stakeholders' perspectives (arguments, prerequisites \& aids) and a collaborative between practical experience and theoretical background (Nerantzidis, 2016, p.301).

As of the practical insights of the literature, the main targeted groups of rating service were investors and bondholders (Donker \& Zahir, 2008, p. 91-92), meanwhile, the benefits would be varying significantly by a wide range of users where the governance value added is already in place for different users (Arndt \& Oman, 2006, p. 46, 92; Baldacchino et al., 2015, p. 53; IFC, 2014, P. 64, 92-93, Kusi et al., 2018, p.271).

To realize the rule of "different benefits for different users", the logic behind setting out our methodology is in action. In another word, all about stakeholders' preferences would carry out in different stages of the construction phase. Thru emphasizing in asking the right question before thinking on the right answer, whereas Quantifying firm's governance performance is not an essence itself, it is a way to measure the evolution of adopting best practices and even set accountability, transparency, integrity deeply rooted in firms, people and countries culture; this enforced End to End processes which focus on the users' perspectives to achieve users' needs and to maintain business potential requirements in the index. 


\section{Corporate Governance Index (CGI) Framework- information system view}
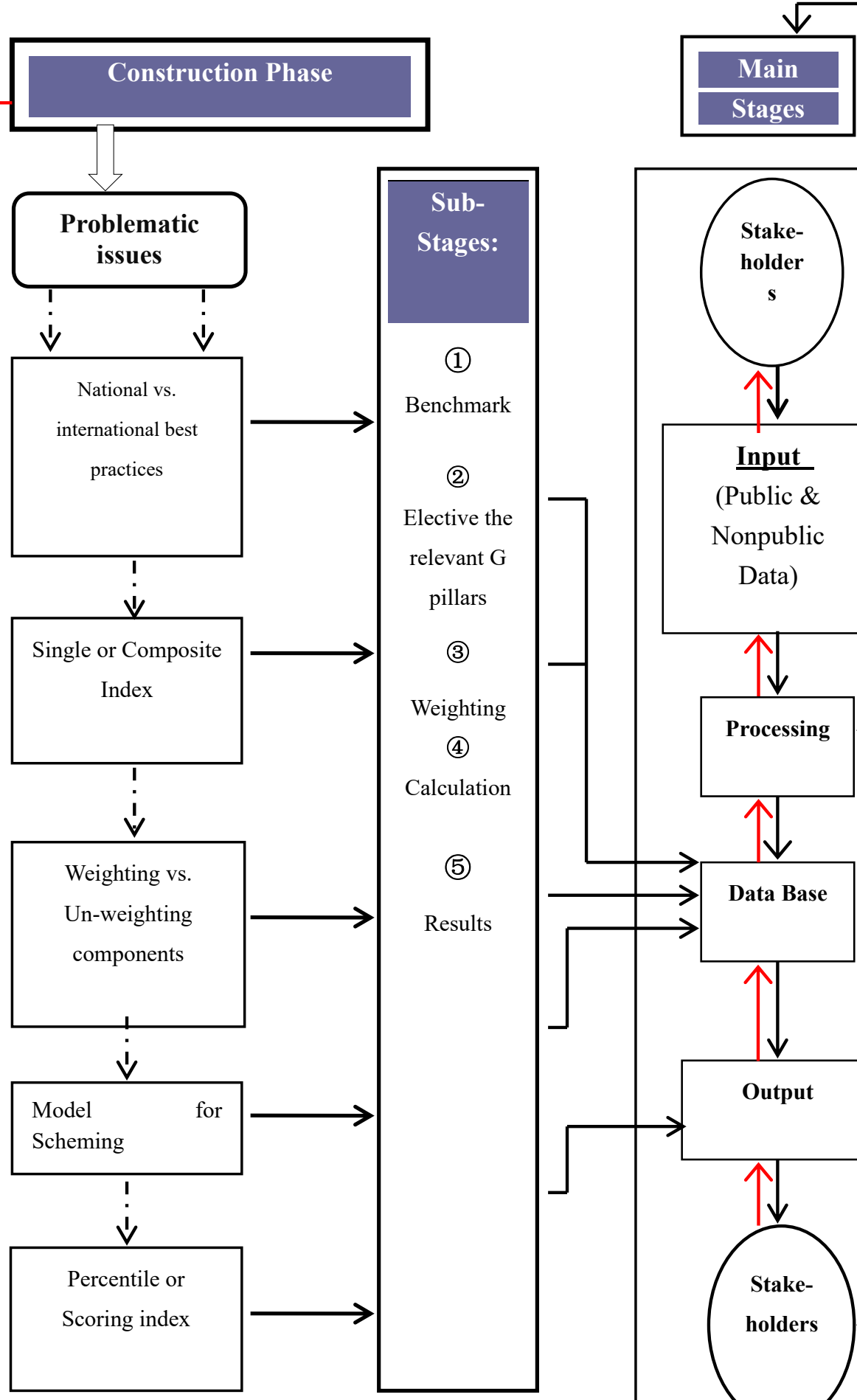

\section{Application Phase}

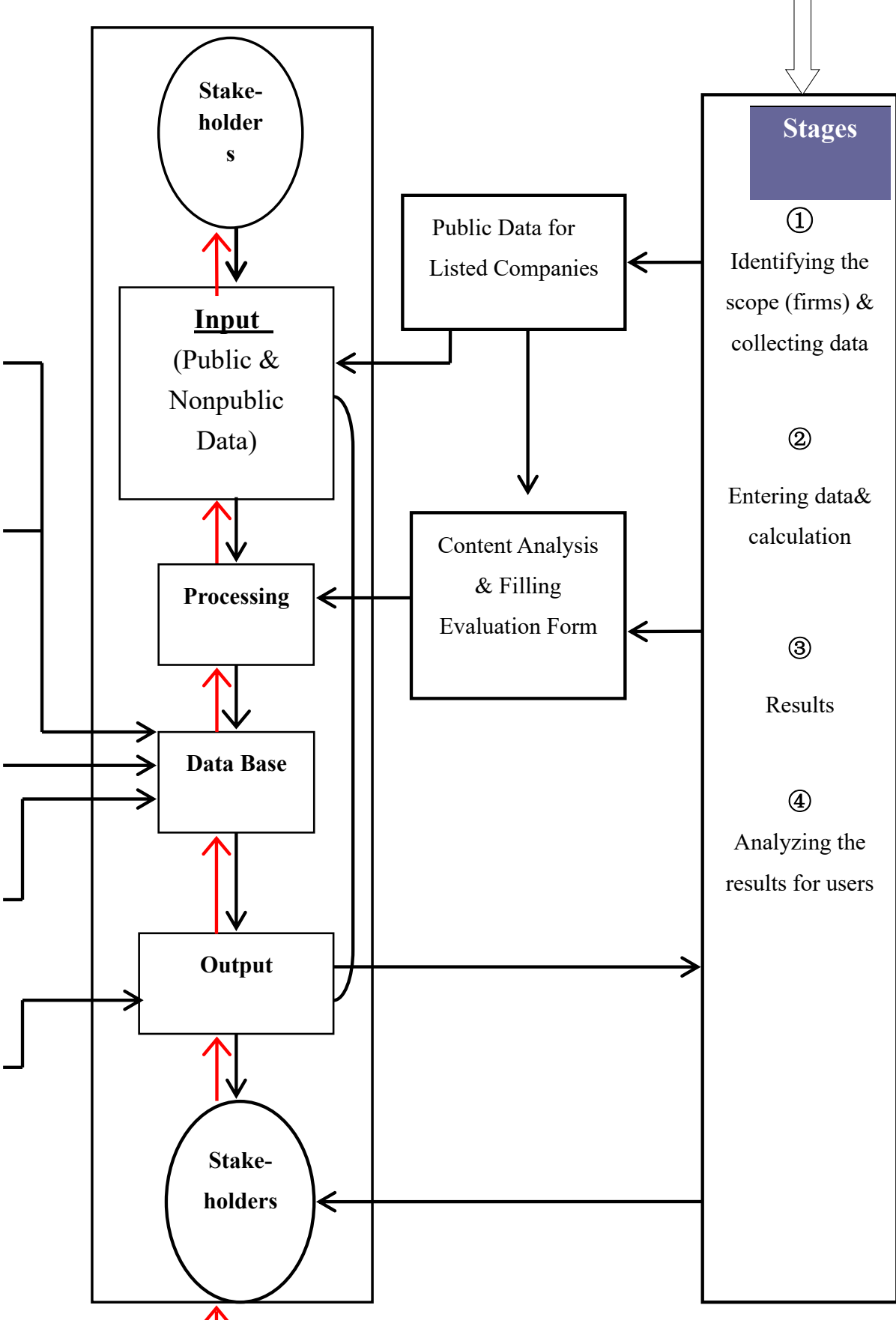

Figure 1. A Conceptual Framework for Building and Conducting CGI 
From that point, the suggested methodology would impose the benefits for all stakeholders and use expert methods to achieve transparency, consensus and validity. The recommended typology will be discussed step-by-step from a system view for establishing the main platform of the corporate governance index and identifying the problematic issues related to each step.

Given the information system view, structuring and implication processes of CGI are compulsory three main steps as displayed from the chart (1);

1. Output Design: The End-to-End Process is used to determine the main objectives of the index, rating users, results formats and frequency and accessibility.

2. Database Design: Multi-methodologies had been used:

- Principle Component Analysis (PCA) is used to extract the appropriate components of the index regarding the stakeholders' views (academics and practitioners) to deal with the problem of lacking theory that reasoning builds a composite index.

- Delphi technique is used to assign the relative weights of the main and sub-criteria of the index, using a sample of experts (academics and practitioners) to yield more reliable priorities.

- Statistical methods (stability Analysis) were implemented to measure the degree of stability and consensus in experts' responses among Delphi rounds and to make a decision of carrying out a further round or stop.

3. Processing Design: Electronic Platform was implemented to organize the main inputs of the CGI (governance criterion and weights) automatically, in order to evaluate a large number of companies easily and fast.

\subsection{Output Design}

Heading for the First stage; i.e., output design, determining the main objectives of the assessment index, outputs' formats, contents, access, frequency, and users are the Preliminary point to develop a governance index (Romney \& Steinbart, 2015, p. 680). We expected that the proposed index aims at benchmarking the listed companies in terms of their commitment and characterizing defects area at the firm level, but at the country level, the index anticipated to determine strengths and weakness in governance framework and the reinforce of regulations and monitor activities.

At the international level, moreover, governance compliance is a way to boost external investors' confidence in the legal system, integrity, insolvency and international credit ratings for countries. Matrix 2 indicates the debatable issues relating to design outputs. 
Table 2. Determinants of Designing the CGI Outputs

\begin{tabular}{ll}
\hline Matrix 2: Determinants of designing the CGI outputs \\
\hline \multicolumn{1}{c}{ Determinants } & \\
\hline 1. Users & Who? $\rightarrow$ Users \\
& How? $\rightarrow$ Forms \\
& When? $\rightarrow$ Time \\
& What? $\rightarrow$ Decisions \\
& Which companies can be evaluated, Listed or non/ big or small? \\
2. Companies & Paper, screen reports, voice, mail or mixed types are used? \\
3. Medium & Which form of output can be presented by; narrative, description, tables or graphs? \\
4. Format & Where is the location of sending outputs? \\
5. Location & Who is authorized to access the original data and results? \\
6. Access & Including details, tables in the final reports or on appendices? \\
7. Details & When and how many times reports are produced? \\
8. Frequency &
\end{tabular}

Based on the first column, there are several determinants given an information system that should be considered in designing the index outputs that starts with identifying the users of outputs. The proposed typology fits the End-to-End process which means that the value starts from stakeholders direct to stakeholders as the end-user of the index outputs, so the stakeholders-orientation is normally the main attitude of the proposed index due to their persuade by the firm's success and/or failure.

The rating output, equally, will be in printed forms published annually for all users. listed firms are incorporated in the assessment process which conducted by specific supervising authority in the first stage to increase objectivity and consistency with the availability of experience and knowledge for external evaluators and then firms can assist in the governance evaluation process for gaining self-assessment experience (IFC, 2014, P. 40).

\subsection{Database Design}

For the second stage; classified as a database design, two main sources of information are an essential input of construction and application phases; (1) Unrestricted Information: related to corporate governance attributes and variables which determined from both national and international governance structures and firms' actual performance interrelated to such variables, such information is publicly available and the researchers did not struggle to collect them (2) restricted information: associated with the first type of information, which needed join forces to determine them, this type of information is related to the relative importance of governance attributes and criteria for the first phase (Balling et al., 2005, p.7, 20; Hitz \& Lehmann, 2015, p.33), and information related to the work effectiveness of governance attributes for the second.

These inputs were derived from the governance benchmark, a distinction between national and international governance codes is the first problematic issue is increasingly recognized and well comprehended in the literature notably in transition economics studies. Whereas 
national governance code is dominant for some academic indices, Khanchel (2007); Martynova \& Renneboog (2010); Grimminger \& Di Benedetta (2013) debated using national governance code absolutely as a guide of firms' governance practices due to the fact that powers and weaknesses of the benchmark will be duplicated in the index, also emerging countries' national governance codes are usually left outdated with respect to rapid changes in the market and users' needs which might less index reliability over time (Khanchel, 2007, p. 743; Martynova \& Renneboog, 2010, p. 2-3; Grimminger \& Di Benedetta, 2013, p.21 Baldacchino et al., 2015, p.47).

Yet, revising the national governance structure would certainly necessitate index adjustment, this represents an opportunity cost of using insufficient governance benchmark, the instructors should go beyond this by maintaining a high level of flexibility via incorporating international best practices as well to meet the acceptable level of convergence in the index results with other indices and increase the comparability among companies in different countries (Brown \& Caylor, 2006, p.412, Martynova \& Renneboog, 2010, p.8). approving with these views to measure the progress of listed firms in adopting good practices and variance of implementation, the researchers incorporated three main benchmarks of the CGI; first, Egyptian governance code revised August 2016; second, OECD principle revised 2015 and finally, ISAR best practices of disclosure in 2005 to match the global requirements in firms' governance systems.

A composite or single index is a second challenge noted by the scholars' quantitative governance studies. Selecting the governance pillars and variables that should be built in the index is a subjective process affected by the developer's judgment and not at ease because of the lacking theory which guides the selection (Balling, 2005, p. 5; Schnyder, 2012, p. 9). Mostafa (2012) states that the electing index component is one of the main challenges of the construction phase, as missing important variables would lead to bias in the results of the index.

Simplistic composition of the single-criterion index is a majority of American governance studies which characterized by shareholders' activism and anti-takeover defense as a way to avoid measurement errors subsequent from selecting irrelevant components and assigning weights for various components (Bhagat et al., 2008, p.1832-1833; Schnyder, 2012, p.2). Even though less complexity in one-dimensional indices have increased the predictive value of the results and reduce the measurement subjectivity, it would mislead index construct validity and measurement objectivity because of unavoidable interrelationships among governance provision; board of directors for example associated with the audit committee, internal and external auditing, and selecting one of these mechanisms as a single dimension of the governance index will be depending on using the others (Donker \& Zhair, 2008, p.90-91).

Meanwhile, composite governance indices are the main attitude of large numbers of professional and academic indices (S\&P's, 2000; Klapper \& Love, 2002; Drobetz et al., 2004; Beiner et al., 2006; Price et al., 2011), but it must sustain efforts to select the appropriate measures to overcome one source of measurement errors which related to involving irrelevant 
governance attributes or including all governance benchmark variables in the index. Such a phenomenon named by Schnyder (2012) as "a kitchen sink problem", G-index produced by Gompers et al. (1995) let fall in "the kitchen sink problem" through using all IRRC governance variables (24 variables) in one index. Cremers \& Nair (2005), Bebchuk et al. (2008) rebuilding G-index mainly focus on the important measures managing by practical insights; they digest 24 variables into 3 and 6 variables.

\subsubsection{Exploratory Factor Analysis and Content Validity}

Combining between scientific and practical background to approach the stakeholder perspectives; is the researchers' way to overcome the lacking theory in selecting the relevant attributes through using Exploratory Factor Analysis (EFA) to convey stakeholders' outlook of the governance principles and the variables that should be built in the index specifically. EFA as a discipline tool to condense related and classified data (Hooper, 2012, p.2); used in little numbers of governance literature (Larcker et al., 2007, Ammann et al., 2009, Holm et al., 2014) to reduce governance variables (Larcker et al., 2007, p.973, Amman et al., 2009, p.45); extract the main pillars of governance (Factors) and Mapping out variables with its correlated pillars.

Principle Component Analysis (PCA) is an EFA widely held tool to achieve the previous goals because of the emphasis on the relationships among governance attributes through screening the loading factor for all variables under each factor (attributes) which ensures induplicate variables that would measure the same features (Balling et al., 2005, p.22). EFA is applied given the following determinants (Anderson, 1974, p. 83; Abdi \& Williams, 2010, p. 434; Rahn, 2017): First; rotate variables using Varimax converged in 50 iterations. Second: Loading Factor $\geq 0.50$ as a rule of variables deletion regardless of sample size; i.e., 120 observations use factor loadings .50 (see Hair et al., 2006, p. Field, 2005); to improve the interpretation of PCA, as a measure of the relation between extracted factors and variables explained by commonalities.

\subsubsection{Modified Delphi Technique and Stability Analysis}

Another increasing debate is how to model a composite index in terms of the relative importance of its components, where there is no convenient approach to weight different variables (Donker \&Zahir, 2008, p.91). An intensive review of the quantitative governance literature by Nerantzidis (2018) stated that 34 studies from 39 followed a dichotomous approach to weight the governance indicators with aim of mitigating subjectivity in personal judgments, enhance transparency and ease of interpretation (Shabbir \& Badgett, 2005, p.10; Beiner et al., 2006, p.258; Haldar \& Rao, 2013; p.17, Tariq \& Abbas, 2013, p.567; Black et al., 2017, p.400)

But relevancy loss derived from weighting inconsistent components equally is the logic behind assigning different weights (Florou \& Galarniotis, 2007, p.984). The relative importance of governance attributes is not identical for countries, companies and stakeholders over periods (Larker et al., 2007, Gherghina et al., 2014, p. 243), such as related party transaction is more important for Enron case (Donker \& Zhair, 2008, p.91), nevertheless 
nominating and compensating committees are dominant in Carillion case.

Commercial and institutional agencies had realized that the costs of using equal weighting assumption outweigh its benefits, definitely these institutions dealing directly with investors and decision-makers; it will lose their clients if the governance evaluation comes with negative impact than users' expectations, hence governance evaluating strategy in action is relatively based on assigning different weights for different components (Nerantizids, 2016, p.301). Expertise and mathematical capability are the rating agencies' tools to make valid and reliable weights (Bhagat et al., 2008, p.1826) and regard as a key reason to explain the wide gap between practitioners and scholars in governance indices as well as lacking theoretical perspective pertaining to verify the relative weights of governance criterion (Larcker et al., 2007, p.965).

In proportion to practical and little academic mindset, the proposed corporate governance index should reveal the importance of its components, which characterized by market attitude toward governance and the progress in adopting governance rules (Daines et al., 2009, p.9), to outline an additive CGI and avoid "tick and sum problem" resulting from simply summing up incompatible measures without reasoning of using equal weights (Strenger, 2004, p. 13, Florou \& Galarniotis, 2007, p. 984, Schnyder, 2012, p. 9); Through conducting modified Delphi Technique.

Delphi Technique is a consensus method conducted in numbers of rounds to converge specialists' views on a specific area and reaching to approval and satisfactory results in case of lacking theory reasoning selection and classification variables (Hill, 1982, Landeta, 2006, Skulmoski et al., 2007, Nerantzidis, 2016). Delphi technique is maintaining participants' anonymity, reduce subjectivity through conducting at least 3 rounds and give opportunities to modify opinions and recognize errors earlier at the end of each one (Gordon, 1994, p.10; Keeney et al., 2001, p. 197; Nworie, 2011, p.28). Further getting the benefits from the modification of the Delphi technique; by utilizing the new technology in Delphi sessions as, sending the Delphi questionnaire via E-mail. The below diagram indicates the determinants and steps had done in Delphi rounds:

As mentioned in Chart (2), The focal point of the Delphi technique, from the above diagram, is selecting the Delphi teamwork which should have the relevant knowledge and ability in governance issues, such as auditors (Cheung et al., 2011), board members (Daines et al., 2009), audit committee members, investors, financial analysts, academics and stock exchange staff (Tsipouri \& Xanthakis, 2004, p.19). Three iterations; as stated by Brooks (1979) are sufficient to reach to consensus in participants' views toward a specific questionnaire, and this depends mainly on the degree of stability among responses.

The degree of stability measured statistically to decide on carrying out a further round or not by calculating the coefficient of variation $(\mathrm{CV})$ between $\mathrm{R} 1$ and $\mathrm{R} 2$ and between R2 and R3which calculated as a ratio of the relation between standard deviation and mean or the average of results for both rounds - and F-test through measure the variance between R1 and R2 (Shan \& Kalaian, 2009, p.228; Nerantzidis, 2016, p.). The stability achieved when the absolute value of the variation in $\mathrm{CV}$ for R2 and R1 gets to a small value and CV R2 should 
be smaller than in $\mathrm{R} 1$ on the first side, and when the value of F-ratio is smaller than or equal on the other side (Shan \& Kalaian, 2009, p.228).

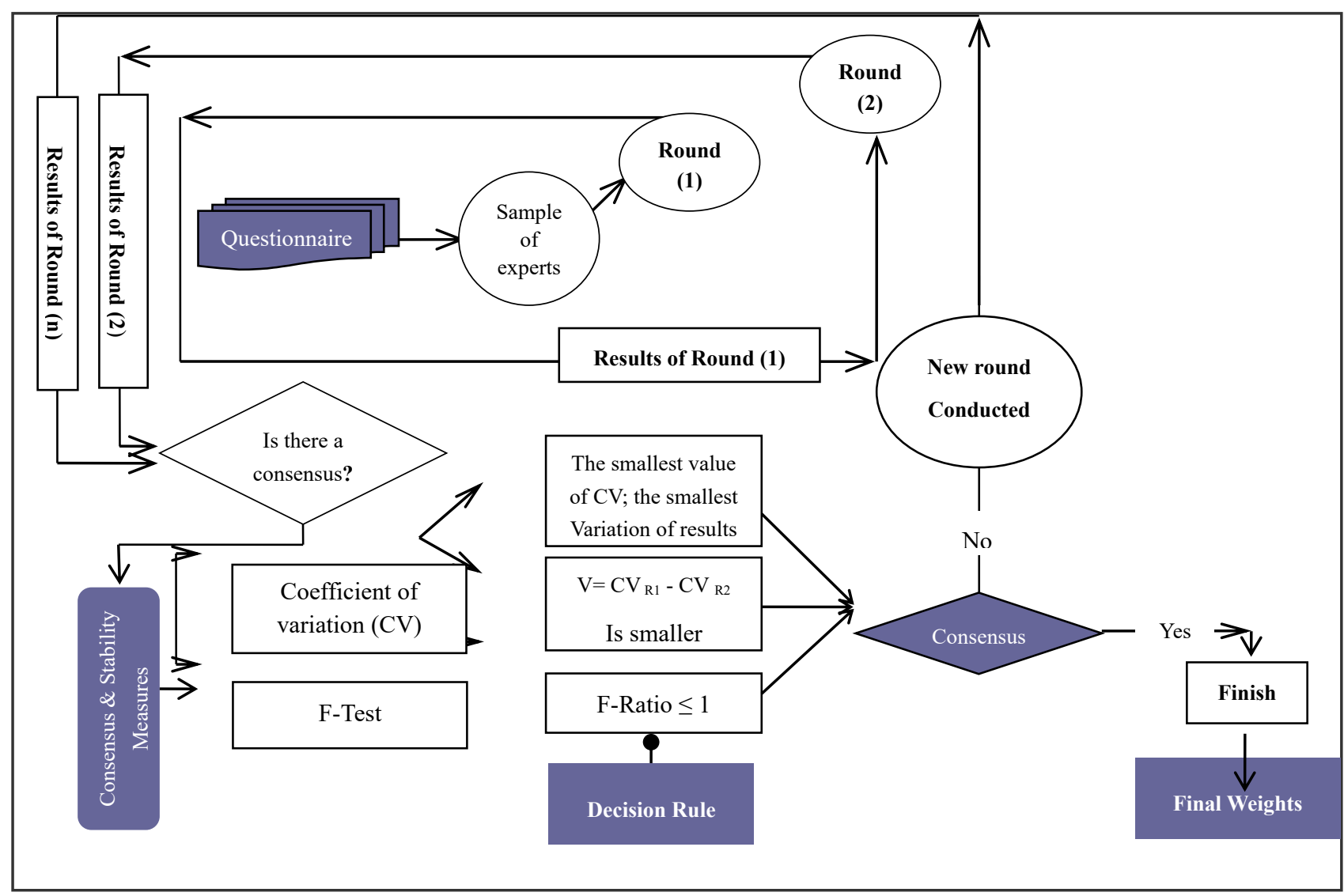

Figure 2. Terms and Conditions of Delphi Technique and Decision Rule of Consensus

\subsection{Processing Design - Scheming Platform and Calculation Process}

Last but not least, structuring the main inputs of the CGI to calculate the results is the last dilemma of the construction phase; IFC has distinguished three types of Scheming Platforms that could be used to manage the data set of the governance assessment: Paper-Based Platform (Text documents); Electronic-Based Platform: in such type, governance criterion and weights are organized automatically using spreadsheets or web-based applications. (IFC, 2014, P. 29-32)

On the way to choose the best platform of valid corporate governance index, clarifies the costs and benefits of paper and electronic platforms are the main triggers to take such decision; however, text documents are simple and easy to use, Commercial CG Rating depends primarily on Technology (Donker \& Zhair, 2008, p.88, Hitz \& Lehmann, 2015, p.7). Web-based applications, alternatively, are suite to evaluate broad companies in various regions automatically and easiest, but spreadsheets are available, commonly used and inexpensive compare to Web-based applications; so, spreadsheets are ideal for structuring 


\section{Mll Macrothink}

and calculating the index results.

On the other hand, CGI is modelling to calculate governance degree of commitment at the firm level by the following formula:

$$
C G I_{K, t}=\sum_{j=1}^{n}\left(\sum_{i=1}^{m} \frac{x_{i j, k}}{M_{j}} * \mathrm{w}_{j}\right) * 100
$$

Where $\mathrm{j}=(1,2 \ldots \mathrm{n}, 5)$

$$
\mathrm{i}=(1,2, \ldots \mathrm{m}, 36)
$$

Subject to:

$$
\sum_{i=1}^{m} W_{j}=1
$$

Where;

- CGI $\mathrm{k}_{\mathrm{t} \text { - }}$ - is the value of a corporate governance index for the company $(\mathrm{k})$ in period $(\mathrm{t})$, ranging from ( 0 to $100 \%$ ), where $100 \%$ is the best level of commitment and zero is the worst.

- $\mathrm{X}_{\mathrm{ij}}$ - represents the actual score of measure (i) under the main pillar (j) weighted by the relative importance of pillar (j).

- $\mathrm{M}_{\mathrm{j}}$ - is the sum of the greatest value which can be assigned to attribute $\mathrm{j}$ for all index pillars where $(j=1 \ldots n, 5)$, and can be calculated via multiplication of greatest score per measure by the number of measures under each provision.

- $\mathrm{W}_{\mathrm{j}}$ - is the assigned weight for the main pillars $(\mathrm{j})$.

Companies are ranked based upon their rating into four groups; each group has a specific color referring to the level of compliance and enhancing the comparability among companies; as shown from the below-ranking line:

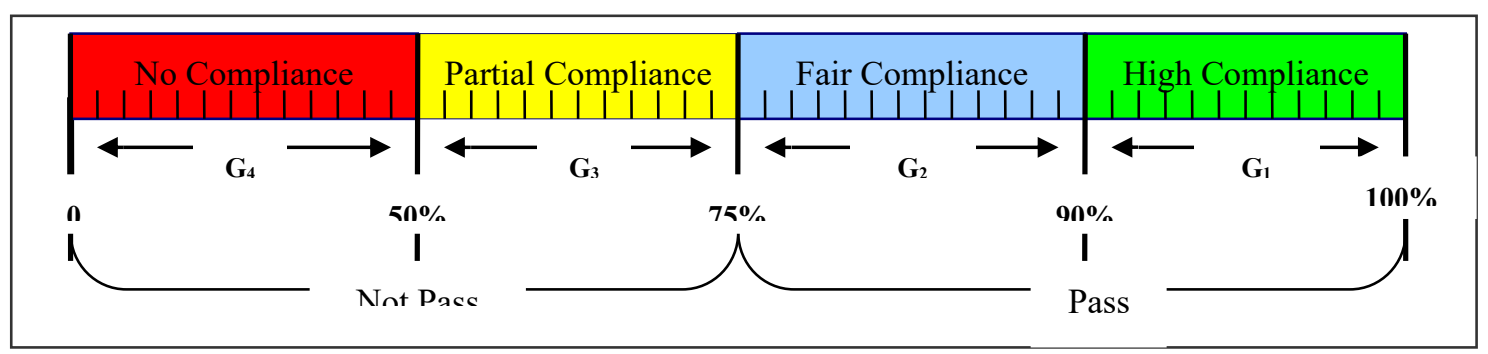

Figure 3. Categorization of Companies in Terms of Their G Ratings 


\section{Macrothink}

Companies with a compliance rate, $\geq 75 \%$ can be classified into two passed groups with two main colors. Green colour means that the company's commitment is in the secure zone; i.e., compliance rate $\geq 90 \%$, and blue colour for $75 \% \leq$ commitment rate $<90 \%$; referring those companies are fair and still needed more effort to improve their situation. Nevertheless, Commitment rate $<75 \%$ is grouping into a non-passed group with two colours; yellow colour -the area of $50 \% \leq$ commitment rate $<75 \%$ - means that the company partially adopts the best practices of good governance and management should direct their attention toward governance practices.

Red colour - $0 \% \leq$ commitment rate $<50 \%$ - indicates that companies are located in a risky area and need to change management attitude regarding the firm's governance structure and performance. At the industry level, the proposed index uses the following equation to discriminate business sectors in terms of their commitment rates:

$$
\operatorname{ACGI}_{I}=\frac{\sum_{K=1}^{L} E C G I_{K}}{\sum_{K=1}^{L} K}
$$

Where;

- ACGII - is the average of the corporate governance index for companies belongs to each industry, ranging from ( 0 to $100 \%$ ), where $100 \%$ is the best level of commitment and zero is the worst.

- K - Signifies as the total number of companies for each industry, $\mathrm{K}$ ranges from $1 \ldots, \mathrm{k}$.

Once an operational structure of the index has been formed, it should be tested on a sample of listed companies. Beyond simple summing up existence and non-existence criteria; the actual governance performance is determined through yearly Evaluation form filings by the non-executive Board members of the targeted sample. Firms' governance practices according to the evaluation form are scored from 0 to 10 ; where score 10 refers that governance, measures work effectively and 0 means it is not in action.

\section{Application Phase}

This section provides the application of the PCA, Delphi technique and the consensus statistical methods separately. Finally, the main results of the applicability of the proposed index are outlined versus the other common approach.

\subsection{Application of PCA}

Matrix 3 and Chart 4 indicate that 12 factors are extracted from applying PCA on 60 governance variables across a sample of stakeholders; which meet the Kaiser rule. These factors are mainly clarifying $51.5 \%$ of governance practices quality. 
Table 3. Factors Extracted from PCA \& Total Variance Explained

\begin{tabular}{ccc}
\hline Matrix 3: Factors extracted from PCA \& total variance explained & \\
\hline Factors & \% of Variance & Cumulative $\%$ \\
\hline Factor 1 & 5.843 & 6.857 \\
Factor 2 & 5.405 & 12.649 \\
Factor 3 & 5.274 & 17.64 \\
Factor 4 & 4.671 & 22.122 \\
Factor 5 & 4.543 & 26.292 \\
Factor 6 & 4.439 & 29.975 \\
Factor 7 & 4.422 & 33.37 \\
Factor 8 & 3.897 & 36.498 \\
Factor 9 & 3.756 & 39.601 \\
Factor 10 & 3.478 & 42.663 \\
Factor 11 & 3.353 & 48.588 \\
Factor 12 & 3.121 & 51.519 \\
\hline
\end{tabular}

As concluded, from the total of 60 governance variables, only 36 have been extracted for the composite CGI. And through mapping of extracted factors to benchmarked governance attributes (Chart 4); the researchers could name the main and minor pillars of the proposed index. As a lack of theory to rationalize the appropriate content of the governance index; the governance regulations have been used to plot the results of exploratory factor analysis for validates the content of the proposed index. As mentioned from Chart (4); the 12 extracted factors are realized five main pillars of benchmarked governance dimensions, which regards board committee construction and functions, companies' procedures conducted to monitor work performance and risk management, the role of internal and external auditing in governing companies, the policy of information disclosure, and finally Board of directors' responsibilities and independence.

Matrix (4) illustrates the selected pillars and measures of the PCA-based governance index. More specifically, there are five main attributes for the CGI; Board Committees, Disclosure \& transparency (T\&D), Firm Policy \& System, Auditing and Internal Control (Auditing \& IC.) and Board of directors (BOD):

- Board of directors, this section provides a general discussion of the board of directors in 4 subsections include board independence; board structure; and areas of explicit board responsibility; board and director evaluation; and director training.

- Board Committee: this attribute includes the general rules of construction and responsibilities of Audit, governance and remuneration committees. The responsibilities of the audit committee, governance, and remuneration committees are tested separately via 12 variables that cover relevance for the reliability of financial reporting, governance compliance, compensation policy, risk assessment, internal controls and firms' policies.

- Disclosure \& transparency: in recent years Requirements for transparency have increased substantially, so the index measures the degree of transparency and disclosure in financial reports and firms' policy relating to disclosure using 5 measures.

- Firm Policy \& System: this section will characterize the general rules of firms' procedures through 8 measures that cover shareholder rights, Equality of disclosure and takeover 


\section{Macrothink}

Journal of Corporate Governance Research

ISSN 1948-4658

2021, Vol. 5, No. 1

defenses compared with general national and industry practice and risk management functions.

- Auditing and Internal Control: the quality of internal control systems, the scope of the audit and non-audit services and auditor's rotation are discussed under this attribute, through 6 measures.

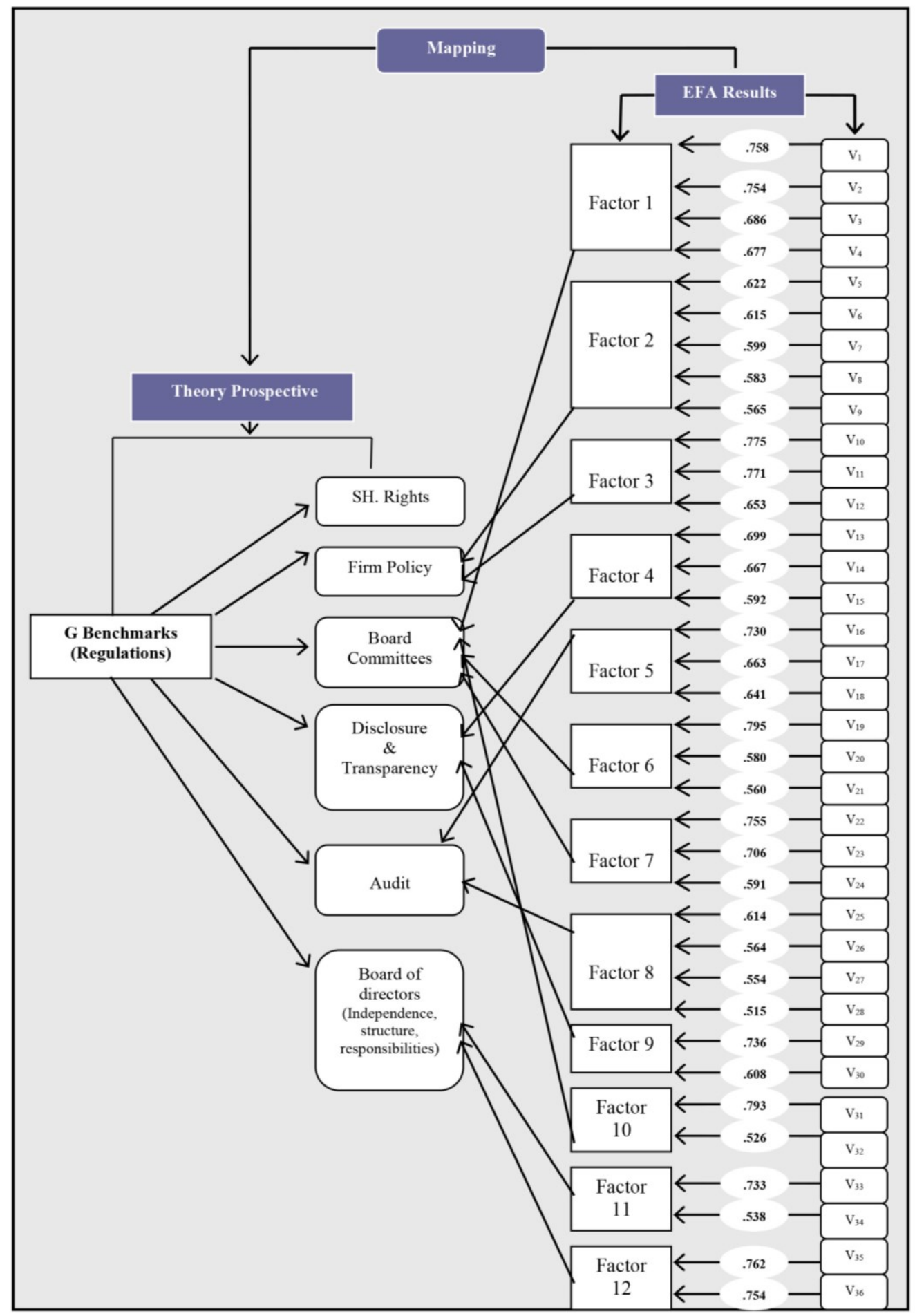

Figure 4. Mapping of Extracted Factors to Benchmarked Governance Attributes 
Table 4. EFA-Based Governance Index Components

Matrix 4: EFA-Based Governance Index Components

\begin{tabular}{|c|c|c|}
\hline \multicolumn{2}{|c|}{ Governance Pillars } & \multirow[t]{2}{*}{ Practical Measures } \\
\hline Minor & Main & \\
\hline$(1)$ & \multirow{4}{*}{$\begin{array}{l}\text { The general policy of } \\
\text { board committees }\end{array}$} & 1. Board committees comprise of at least three non- executive board members \\
\hline \multirow[t]{11}{*}{$\begin{array}{l}\text { Board } \\
\text { Committees }\end{array}$} & & $\begin{array}{l}\text { 2. Board committee meetings comprised of at least three months and would be } \\
\text { correct at } 50 \% \text { of attendance or minimum level of construction }\end{array}$ \\
\hline & & $\begin{array}{l}\text { 3. Board of directors confirm the composition and responsibilities of the board } \\
\text { committee }\end{array}$ \\
\hline & & $\begin{array}{l}\text { 4. Board should be comprised of a majority of non- executive and expertise in } \\
\text { company's activities }\end{array}$ \\
\hline & \multirow[t]{3}{*}{$\begin{array}{l}\text { Audit committee } \\
\text { responsibilities }\end{array}$} & $\begin{array}{l}\text { 5. Approved the decision of auditor appointment, and reviewing the audit plan, } \\
\text { auditor's recommendations and firm responses. }\end{array}$ \\
\hline & & $\begin{array}{l}\text { 6. Approved the decision of selection, dismissal and financial terms of the head of } \\
\text { internal control and internal audit. }\end{array}$ \\
\hline & & $\begin{array}{l}\text { 7. Overseeing financial statements \& accounting policies before reporting to the } \\
\text { board. }\end{array}$ \\
\hline & $\begin{array}{l}\text { Governance } \\
\text { Committee Functions }\end{array}$ & $\begin{array}{l}\text { 8. Supervising firm's governance structure and preparing a report on firm } \\
\text { compliance with G Code. }\end{array}$ \\
\hline & & 9. Reviewing annual reports and board reports in terms of governance issues. \\
\hline & & 10. Disclosing on material risks and exist actions to fight them. \\
\hline & $\begin{array}{l}\text { Remuneration } \\
\text { committee functions }\end{array}$ & $\begin{array}{l}\text { 11. Compensating of board committee members and large executives depending } \\
\text { on performance standards and confirms no conflicts with firms' policies. }\end{array}$ \\
\hline & & $\begin{array}{l}\text { 12. Reviewing Disclosure relates to the benefits and compensations policy of the } \\
\text { board, committee members and large executives during the year. }\end{array}$ \\
\hline \multirow{8}{*}{$\begin{array}{l}(2) \\
\text { Firm Policy \& } \\
\text { System }\end{array}$} & \multirow{5}{*}{ General rules } & $\begin{array}{l}\text { 13. Listed companies should disclose their board committee composition and the } \\
\text { balance between executives and non-executives. }\end{array}$ \\
\hline & & $\begin{array}{l}\text { 14. Acquisitions of shares by firms' directors or employees must be disclosed and } \\
\text { organized by firm rules. }\end{array}$ \\
\hline & & $\begin{array}{l}\text { 15. Shareholders have the rights to access, vote and participate in general } \\
\text { assembly by post or proxy. }\end{array}$ \\
\hline & & 16. Equality of disclosure to maintain minority shareholders rights. \\
\hline & & 17. Disclosure on related party transactions with internal and external parties. \\
\hline & \multirow{3}{*}{$\begin{array}{l}\text { Functioning of risk } \\
\text { Management }\end{array}$} & 18. Assessing the acceptable level of risks and establish proxies to measure risks. \\
\hline & & 19. Analyzing, assessing and reporting the firm risks \\
\hline & & $\begin{array}{l}\text { 20. Reviewing the reports of activity risks and tacking actions before reporting on } \\
\text { the board. }\end{array}$ \\
\hline (3) & \multirow{2}{*}{$\begin{array}{l}\text { The general policy of } \\
\text { disclosure }\end{array}$} & 21. Annual reports should include financial and non-financial information \\
\hline $\begin{array}{l}\text { Transparency } \\
\qquad \&\end{array}$ & & $\begin{array}{l}\text { 22. Disclosed information should have good characteristics of information quality; } \\
\text { transparency, completeness, comparability, timeliness. }\end{array}$ \\
\hline \multirow{3}{*}{$\begin{array}{l}\text { Disclosure } \\
\text { (T\&D) }\end{array}$} & \multirow{4}{*}{ D. items } & 23. Firms' websites should be stimulating and updating regularly. \\
\hline & & 24. Disclosure on Equity Structure including voting rights. \\
\hline & & 25. Disclosure of accounting estimates and policies. \\
\hline (4) & & $\begin{array}{l}\text { 26. Functional reporting to the audit committee or board directly and } \\
\text { administrative reporting to the Chief Executive Officer (CEO). }\end{array}$ \\
\hline
\end{tabular}




\section{Macrothink}

Journal of Corporate Governance Research

ISSN 1948-4658

2021, Vol. 5, No. 1

\begin{tabular}{|c|c|c|}
\hline Audit \& & Internal Audit & 27. Ensuring the firm's conducting a code of ethics, rules and policies. \\
\hline $\begin{array}{l}\text { Internal Control } \\
\text { (Auditing \& IC) }\end{array}$ & & $\begin{array}{l}\text { 28. Evaluating and reporting to the audit committee on the effectiveness of internal } \\
\text { control. }\end{array}$ \\
\hline & & 29. Auditors rotating after 5 years and do not reappoint before 3 years \\
\hline & External audit & $\begin{array}{l}\text { 30. General assembly is appointing an external auditor or more depends upon the } \\
\text { approval of the board and audit committee. }\end{array}$ \\
\hline & & $\begin{array}{l}\text { 31. Audit committee should be approved the non-audit services provided by the } \\
\text { firm's auditor to maintain the auditor's independence. And non-audit fees should } \\
\text { be balanced with audit fees. }\end{array}$ \\
\hline & & $\begin{array}{l}\text { 32. CEO duality is not supported, if not a firm should disclose in annual reports } \\
\text { and websites. }\end{array}$ \\
\hline $\begin{array}{c}\text { (5) } \\
\text { Board of }\end{array}$ & Board functions & $\begin{array}{l}\text { 33. Training of board members and employees including corporate governance } \\
\text { culture. }\end{array}$ \\
\hline $\begin{array}{l}\text { Directors } \\
\text { (BOD) }\end{array}$ & & $\begin{array}{l}\text { 34. General oversight on information disclosure to maintain the integrity of annual } \\
\text { reports. }\end{array}$ \\
\hline & Board independence & 35. Board comprises at least two independent members with experience. \\
\hline & & $\begin{array}{l}\text { 36. Board independence should be maintained through disclosing direct/indirect } \\
\text { interests in the company. }\end{array}$ \\
\hline
\end{tabular}

\subsection{Application of Delphi Technique}

Table 5. Sample Size of Delphi Rounds

\begin{tabular}{|c|c|c|c|c|}
\hline \multicolumn{5}{|c|}{ Matrix 5: Sample size of Delphi rounds } \\
\hline \multicolumn{3}{|c|}{ Delphi teamwork proficiency themes } & \multirow{2}{*}{$\begin{array}{l}\% \\
3\end{array}$} & \multirow{2}{*}{$\begin{array}{l}\mathrm{N} \\
.3\end{array}$} \\
\hline Experience & \multirow{4}{*}{ Years } & $15 \geq$ years $\leq 20$ & & \\
\hline & & $21-30$ & 2 & .2 \\
\hline & & $\geq 30$ & 5 & .5 \\
\hline & & Sum & 10 & 1 \\
\hline & \multirow{6}{*}{ Field } & Board members & 4 & \\
\hline & & Audit committee members & 5 & \\
\hline & & members & & \\
\hline & & Auditors & 5 & \\
\hline & & Academics & 9 & \\
\hline & & Stock exchange expert & 2 & \\
\hline \multirow[t]{2}{*}{ Qualifications } & Academic & PhD. & 8 & \\
\hline & Professional & CMA, CIA, others & 4 & \\
\hline \multirow[t]{3}{*}{ Major } & Accounting and Auditing & & 8 & .8 \\
\hline & Management & & 2 & .2 \\
\hline & Sum & & 10 & 1 \\
\hline
\end{tabular}


Matrix 5 indicates the experts' sample of Delphi rounds; 10 experts have involved in Delphi rounds; lasted from February to May 2018. Based on some proficiency themes; we select the Delphi teamwork. For instance, the examiner should have at least 15 years of experience in governance for academic and non-academic. And relating to qualifications, an academic should hold a $\mathrm{PhD}$ in the $\mathrm{CG}$ or management, practitioners should hold relevant professional certificates.

From the total number of Delphi sample; academics, board members, audit committee members, auditors, and Stock Exchange Expert, 50\% of Delphi teamwork has more than 30 years of experience in governance and auditing and $80 \%$ of the team works in accounting and auditing major while $20 \%$ in management. On the other hand, $80 \%$ of the team holds a $\mathrm{PhD}$ degree and $30 \%$ has professional certificates.

The researchers found that almost the degree of consensus in experts' views was obtained at the end of round three. In round one, all participants put their opinion and expectations about the importance of governance pillars individually based mainly on their awareness and proficiency through sustaining the anonymity of all participants. Matrix 6 shows the results of iteration one of the Delphi technique:

Table 6. Results of Delphi Round One $\left(\mathrm{R}_{1}\right) \%$

\begin{tabular}{|c|c|c|c|c|c|c|c|c|c|c|}
\hline \multicolumn{11}{|c|}{ Matrix 6: Results of Delphi Round One $\left(\mathrm{R}_{1}\right) \%$} \\
\hline $\begin{array}{c}\text { Governance Main } \\
\text { Pillars }\end{array}$ & $\begin{array}{c}\text { Expert } \\
(1)\end{array}$ & $\begin{array}{c}\text { Expert } \\
(2)\end{array}$ & $\begin{array}{c}\text { Expert } \\
(3)\end{array}$ & $\begin{array}{c}\text { Expert } \\
(4)\end{array}$ & $\begin{array}{c}\text { Expert } \\
(5)\end{array}$ & $\begin{array}{c}\text { Expert } \\
(6)\end{array}$ & $\begin{array}{c}\text { Expert } \\
(7)\end{array}$ & $\begin{array}{c}\text { Expert } \\
(8)\end{array}$ & $\begin{array}{c}\text { Expert } \\
(9)\end{array}$ & $\begin{array}{c}\text { Expert } \\
(10)\end{array}$ \\
\hline 1. Board & 10 & 15 & 5 & 10 & 20 & 10 & 10 & 10 & 20 & 10 \\
\hline \multicolumn{11}{|l|}{ Committees } \\
\hline 2. Firm Policy & 20 & 20 & 25 & 25 & 30 & 30 & 20 & 20 & 20 & 20 \\
\hline 3. $\mathrm{T} \& \mathrm{D}$ & 30 & 25 & 40 & 25 & 30 & 25 & 30 & 25 & 20 & 10 \\
\hline 4. Auditing \& IC. & 20 & 15 & 15 & 15 & 10 & 15 & 10 & 20 & 20 & 40 \\
\hline 5. BOD & 20 & 25 & 15 & 25 & 10 & 20 & 30 & 25 & 20 & 20 \\
\hline SUM & $100 \%$ & $100 \%$ & $100 \%$ & $100 \%$ & $100 \%$ & $100 \%$ & $100 \%$ & $100 \%$ & $100 \%$ & $100 \%$ \\
\hline
\end{tabular}

As a result of round $1(\mathrm{R} 1)$, Disclosure \& Transparency has the highest priority among the components of the index followed by firms' policy and Board of directors, almost $26 \%, 23 \%$, $21 \%$ respectively. Nevertheless, Board committees have the lowest priority almost $12 \%$. These results have been organized to view all the experts' views with a veil of the character of participants, forgetting; an opportunity to revise and adjust their perceptions in terms of other expertise in round two. The below table mentions the results of the second iteration of Delphi rounds: 
Table 7. Results of Delphi Round Two $\left(\mathrm{R}_{2}\right) \%$

\begin{tabular}{|c|c|c|c|c|c|c|c|c|c|c|}
\hline $\begin{array}{l}\text { Governance Main } \\
\text { Pillars }\end{array}$ & $\begin{array}{l}\text { Expert } \\
\text { (1) }\end{array}$ & $\begin{array}{l}\text { Expert } \\
(2)\end{array}$ & $\begin{array}{l}\text { Expert } \\
\text { (3) }\end{array}$ & $\begin{array}{l}\text { Expert } \\
(4)\end{array}$ & $\begin{array}{l}\text { Expert } \\
(5)\end{array}$ & $\begin{array}{l}\text { Expert } \\
(6)\end{array}$ & $\begin{array}{l}\text { Expert } \\
\text { (7) }\end{array}$ & $\begin{array}{l}\text { Expert } \\
(8)\end{array}$ & $\begin{array}{l}\text { Expert } \\
\text { (9) }\end{array}$ & $\begin{array}{l}\text { Expert } \\
(10)\end{array}$ \\
\hline 1. Board Committees & 10 & 20 & 10 & 15 & 5 & 10 & 15 & 10 & 10 & 10 \\
\hline 2. Firm Policy & 20 & 20 & 25 & 25 & 25 & 25 & 25 & 30 & 20 & 20 \\
\hline 3. D \& T & 25 & 20 & 25 & 10 & 30 & 30 & 30 & 30 & 20 & 20 \\
\hline 4. Auditing \& IC. & 20 & 15 & 15 & 10 & 10 & 20 & 10 & 10 & 20 & 30 \\
\hline 5. BOD & 25 & 25 & 25 & 40 & 30 & 15 & 20 & 20 & 30 & 20 \\
\hline SUM & $100 \%$ & $100 \%$ & $100 \%$ & $100 \%$ & $100 \%$ & $100 \%$ & $100 \%$ & $100 \%$ & $100 \%$ & $100 \%$ \\
\hline
\end{tabular}

As a result of round 2 (R2), the priorities have changed significantly from R1, for example, the first priority is assigned for the board of directors by $25 \%$ and the second and third priority assigned for Disclosure \& Transparency and firms' policy by 24\%, 23.5\% respectively. Given that differences, the researchers should conduct the Stability Analysis in order to measure the degree of consensus in Delphi responses in R2 compared to R1, which discussed in the next section.

\subsection{Application of Stability Analysis}

The CV and F-ratio analysis were conducted to measure the degree of consensus in opinions of the Delphi teamwork. Matrix 7 indicates that $\mathrm{CV}$ was decreased for all governance pillars except the last one (Board of Directors); ever since, the CV for board committees; firm policy; disclosure \& transparency and auditing \& Internal Control in round one was $40 \%, 18 \%, 29 \%$, $47 \%$ respectively, compared to $35 \%, 14 \%, 21 \%, 41 \%$ in round two. Nevertheless; CV was increased from $27 \%$ to $28 \%$ for the board of directors. So, a third-round would trigger to match the consensus and stability rule.

Table 8. Stability and Consensus Tests Results for $\left(R_{1}\right) \&\left(R_{2}\right)$

\begin{tabular}{lcccccc}
\hline \multicolumn{2}{l}{ Matrix 8: Stability and Consensus Tests Results for $\left(\mathrm{R}_{1}\right) \&\left(\mathrm{R}_{2}\right)$} \\
\hline \multicolumn{2}{l}{ Statistic } & \multicolumn{7}{l}{ Board Committees } & Firm Policy & T\& D & Auditing \& IC. & BOD \\
\hline \multirow{2}{*}{ Mean } & $\left(\mathrm{R}_{1}\right)$ & 12 & 23 & 26 & 18 & 21 \\
Std. & $\left(\mathrm{R}_{2}\right)$ & 11.5 & 23.5 & 24 & 16 & 25 \\
Deviation & $\left(\sigma ; \mathrm{R}_{1}\right)$ & 4.83 & 4.216 & 7.746 & 8.563 & 5.676 \\
& $\left(\sigma ; \mathrm{R}_{2}\right)$ & 4.116 & 3.375 & 6.583 & 6.583 & 7.071 \\
Variance & $\left(\sigma^{2} ; \mathrm{R}_{1}\right)$ & 23.333 & 17.778 & 60 & 73.333 & 32.222 \\
& $\left(\sigma^{2} ; \mathrm{R}_{2}\right)$ & 16.944 & 11.389 & 43.333 & 43.333 & 50 \\
$\mathrm{CV}$ & $\mathrm{R}_{1}$ & 0.4025 & 0.1833 & 0.2979 & 0.4757 & 0.2702 \\
V=CV & $\mathrm{R}_{2}-\mathrm{CV}$ & 0.3579 & 0.1436 & 0.2742 & 0.4114 & 0.2828 \\
F-Ratio & & 0.04458 & 0.0396 & 0.0236 & 0.0642 & -0.0125 \\
\hline
\end{tabular}

On the other hand, F-Ratio proves the results of CV measure, since F- Ratios for all governance pillars were less than one except the last pillar; which had a ratio greater than one and this was confirmed the validity of further Delphi round for altering team judgments. The 
following matrix indicates third round assessments and final weights calculated as an average of ten experts' views:

Table 9. Results of Delphi Round Three (R3) \%

\begin{tabular}{lcccccccccc}
\hline Matrix 9: Results of Delphi Round Three $\left(\mathrm{R}_{3}\right) \%$ \\
\hline \multicolumn{1}{c}{ Governance Main } & $\begin{array}{c}\text { Expert } \\
\text { Pillars }\end{array}$ & $\begin{array}{c}\text { Expert } \\
\text { Expert }\end{array}$ & $\begin{array}{c}\text { Expert } \\
(2)\end{array}$ & $\begin{array}{c}\text { Expert } \\
\text { Expert }\end{array}$ & $\begin{array}{c}\text { Expert } \\
\text { Expert }\end{array}$ & $\begin{array}{c}\text { Expert } \\
\text { Expert }\end{array}$ & $\begin{array}{c}\text { Exp) } \\
(10)\end{array}$ \\
\hline 1. Board Committees & 10 & 15 & 10 & 10 & 10 & 15 & 10 & 10 & 10 & 10 \\
2. Firm Policy & 20 & 20 & 25 & 25 & 25 & 25 & 25 & 20 & 25 & 20 \\
3. T\&D & 25 & 25 & 25 & 30 & 30 & 30 & 30 & 20 & 25 & 20 \\
4. Auditing \& IC. & 20 & 15 & 15 & 10 & 20 & 10 & 10 & 20 & 15 & 30 \\
5. BOD & 25 & 25 & 25 & 25 & 15 & 20 & 25 & 30 & 25 & 20 \\
\multicolumn{1}{c}{ SUM } & $100 \%$ & $100 \%$ & $100 \%$ & $100 \%$ & $100 \%$ & $100 \%$ & $100 \%$ & $100 \%$ & $100 \%$ & $100 \%$ \\
\hline
\end{tabular}

As mentioned earlier, the decision of ending the Delphi process needs statistical tests to measure the extent of stability among the experts' views; so, CV and F-Ratio have been calculated for such purpose. It is seen from table 13 that $\mathrm{CV}$ of $\mathrm{R} 3$ was smaller for all governance attributes than in R2; because the CV for board committees; firm policy; disclosure \& transparency; auditing \& Internal Control and Board of Directors in round three were $19 \%, 11 \%, 15 \%, 37 \%$, and $17 \%$ respectively, compared to $35 \%, 14 \%, 21 \%, 41 \%$ and $28 \%$ in round two. Moreover, the variations (V) between R3 and R2 were shifted than between R2 and R1. Conversely, F-Ratio for all attributes was less than 1 as seen; which means that stability in experts' perceptions have been attained for all pillars in round three and that was the end of Delphi iterations.

Table 10. Stability and Consensus Tests Results for $\left(\mathrm{R}_{3}\right) \%$

\begin{tabular}{|c|c|c|c|c|c|}
\hline \multicolumn{6}{|c|}{ Matrix 10: Stability and Consensus tests results for $\left(\mathrm{R}_{3}\right) \%$} \\
\hline Statistic & Board Committees & Firm Policy & $\mathrm{T} \& \mathrm{D}$ & Auditing \& IC. & BOD \\
\hline Mean $\left(\mathrm{R}_{3}\right)$ & 11 & 23 & 26 & 16.5 & 23.5 \\
\hline Std. Deviation & 2.108 & 2.582 & 3.944 & 6.258 & 4.116 \\
\hline Variance $\left(\mathrm{R}_{3}\right)$ & 4.444 & 6.667 & 15.556 & 39.167 & 16.944 \\
\hline $\mathrm{CV}\left(\mathrm{R}_{3}\right)$ & 0.1916 & 0.1122 & 0.1516 & 0.3792 & 0.1751 \\
\hline $\mathrm{V}=\mathrm{CV}_{\mathrm{R} 2}-\mathrm{CV}_{\mathrm{R} 3}$ & 0.1663 & 0.0314 & 0.1226 & 0.0322 & 0.1077 \\
\hline F -Ratio & 0.0113 & 0.0098 & 0.0034 & 0.0087 & 0.0035 \\
\hline
\end{tabular}

Accordingly, the researchers concluded that disclosure and transparency; board of directors (functions and independence) and firm policy (risk management and general rules) are the main priority of governance criterion by $26 \%, 23.5 \%$, and $23 \%$ respectively and sampled experts had reasoned the prioritization of such pillars by the importance of conducting the code of ethics and internal control mechanisms to support transparency, shareholders rights 
and company reputation to achieve stakeholders satisfaction.

\subsection{The Applicability of the Proposed Index}

Once an operational structure of the index has been formed, it should be tested on a sample of listed companies. Beyond simple summing up existence and non-existence corporate governance criteria; the actual governance performance of tested firms is determined through yearly Evaluation form filings by the non-executive Board of directors' members of the targeted sample. Firms' governance practices according to the evaluation form are scored from 0 to 10; where score 10 refers that governance, variables are work effectively and 0 means it is not in action. Collected scores were processed using the index commitment formula (see section 3.3) to investigate the progress of adopting good governance rules in practice, identifying the differences among Companies regarding their sensitivity and perceptions of governance guidance, and exploring the role of different industries in boosting the espousal of good governance and ethical issues.

Table (11) presents the CG disclosure ratings calculated for the tested companies based on two main views; weighted attributes (W) and equally weighted attributes (E). The last set of columns shows that the compliance was partially and deviated in all governance attributes. Firm 8 and 9 are the top-ranked companies with a compliance rate of $76 \%$ from $100 \%$ and followed by firm 7 with a compliance rate equal to $74 \%$. Meanwhile, the progress of adopting best practices is relatively low, but it's ever closest to the World Bank (2009) and the European bank (2017) assessment of such Companies in 2009 and 2017 respectively.

Table 11. Results of Assessing Governance Practices for Tested Companies Using CGI

\begin{tabular}{|c|c|c|c|c|c|c|c|c|c|c|c|c|c|c|c|c|c|c|c|c|c|c|}
\hline \multirow[t]{2}{*}{ Weight } & \multirow[t]{2}{*}{ G. Pillars } & \multicolumn{2}{|c|}{ (1) } & \multicolumn{2}{|c|}{$\mathrm{F}(2)$} & \multicolumn{2}{|c|}{ (3) } & \multicolumn{2}{|c|}{ (4) } & \multicolumn{2}{|c|}{ (5) } & \multicolumn{2}{|c|}{ (6) } & \multicolumn{2}{|c|}{ (7) } & \multicolumn{2}{|c|}{ (8) } & \multicolumn{2}{|c|}{ (9) } & \multicolumn{2}{|c|}{ (10) } & \multirow[t]{2}{*}{ Mean } \\
\hline & & W & E & W & E & W & E & W & $\mathrm{E}$ & W & E & W & $\mathrm{E}$ & W & $\mathrm{E}$ & W & E & W & E & W & E & \\
\hline 0.11 & $\begin{array}{c}\text { Board } \\
\text { Committee }\end{array}$ & $\begin{array}{l}\text { in } \\
\text { in }\end{array}$ & $\dot{亠}_{\infty}$ & : & $\dot{\bar{n}}$ & ஜ் & $\dot{N}$ & $\dot{\circ}$ & $\dot{\omega}$ & ஜ் & $\dot{\omega}$ & ஜே & 岕 & $\dot{8}$ & 颉 & $\dot{8}$ & 옹 & $\stackrel{\circ}{\circ}$ & $\dot{\sigma}$ & $\dot{8}$ & i̊ & $\dot{\dot{v}}$ \\
\hline 0.23 & $\begin{array}{c}\text { Firm } \\
\text { Policies }\end{array}$ & $\underline{\underline{z}}$ & ओं & 8 & ஜ் & 운 & $\frac{N}{N}$ & : & is & 8 & ட & $\stackrel{\circ}{\vec{v}}$ & $\dot{\bar{\infty}}$ & : & ฉ & $\stackrel{\circ}{\dot{u}}$ & 亏ু & $\stackrel{\circ}{\circ}$ & $\dot{\bar{N}}$ & $\stackrel{\circ}{\dot{u}}$ & $\dot{\omega}$ & $\stackrel{\circ}{\mathrm{N}}$ \\
\hline 0.26 & $\mathrm{~T} \& \mathrm{D}$ & i & $\underset{\infty}{\infty}$ & i & : & i & 8 & i & $\dot{\infty}_{\infty}^{\infty}$ & i & ஓ & i & $\stackrel{\infty}{\infty}$ & 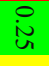 & : & i & $\stackrel{2}{\infty}$ & $\stackrel{\circ}{\infty}$ & 우 & $\stackrel{\circ}{\infty}$ & $\dot{y}$ & 离 \\
\hline 0.17 & $\begin{array}{l}\text { Auditing } \\
\text { and IC. }\end{array}$ & $\stackrel{\circ}{\mathrm{N}}$ & $\dot{\check{\alpha}}$ & $\stackrel{\circ}{\dot{u}}$ & $\dot{\tilde{N}}$ & $\stackrel{\circ}{=}$ & \& & $\stackrel{\circ}{=}$ & 8 & $\stackrel{\circ}{=}$ & : & $\stackrel{\circ}{=}$ & : & $\dot{\mathrm{N}}$ & $\dot{0}$ & $\stackrel{\circ}{\dot{n}}$ & $\dot{0}$ & $\stackrel{\circ}{\not}$ & $\bar{\sigma}$ & $\stackrel{\circ}{\not}$ & $\dot{\bar{\infty}}$ & $\stackrel{\circ}{\dot{N}}$ \\
\hline \multirow[t]{2}{*}{0.24} & BOD & $\stackrel{\circ}{y}$ & ن্. & $\stackrel{\circ}{\dot{u}}$ & 灾 & $\stackrel{\circ}{\perp}$ & $i_{\infty}^{\infty}$ & $\stackrel{\circ}{\dot{u}}$ & 寍 & $\stackrel{\circ}{v}$ & i. & : & $\underset{\sim}{\stackrel{\sim}{\sim}}$ & $\stackrel{\circ}{\infty}$ & ட் & $\stackrel{\circ}{\infty}$ & ட் & in & $\stackrel{\infty}{\infty}$ & : & 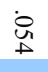 & $\stackrel{\circ}{\dot{\sigma}}$ \\
\hline & Total & & & & & & & & & & & & & & & & & & & & & \\
\hline \multirow[t]{5}{*}{1} & Score & \multicolumn{2}{|c|}{223} & \multicolumn{2}{|c|}{227} & \multicolumn{2}{|c|}{212} & \multicolumn{2}{|c|}{215} & \multicolumn{2}{|c|}{215} & \multicolumn{2}{|c|}{229} & \multicolumn{2}{|c|}{263} & \multicolumn{2}{|c|}{272} & \multicolumn{2}{|c|}{271} & \multicolumn{2}{|c|}{273} & 240 \\
\hline & Total & & & & & & & & & & & & & & & & & & & & & \\
\hline & Averaged & & & & & & & & & & & & & & & & & & & & & \\
\hline & Score & $\begin{array}{l}\dot{\theta} \\
\dot{8}\end{array}$ & & $\dot{\dot{\alpha}}$ & & $\begin{array}{l}\text { ì } \\
1\end{array}$ & & : & & ஷ் & & ஷ் & & $\stackrel{\dot{u}}{\sim}$ & is & $\stackrel{\bullet}{\breve{y}}$ & in & $\stackrel{\circ}{y}$ & in & $\stackrel{\stackrel{\sim}{\omega}}{ }$ & in & $\stackrel{\ominus}{i}$ \\
\hline & Ranking & 5 & & 6 & & 0 & & 9 & & 7 & & 8 & & 3 & & 2 & & 1 & & 4 & & \\
\hline
\end{tabular}


Whereas, the results show that a soaring proportion of compliance was related to Disclosure and Transparency, where $90 \%$ of firms are formally committed and they were ranked in group one and group two. While almost half of the firms are inadequately governing their policies and rules compared to the Board of directors (independence \& responsibilities) and auditing \& internal control provisions.

Evaluating the strengthens and weakness in governance practices of tested firms are ensuring that there is an agreement among the three assessment approaches are in some cases, such as, ownership concentration (family corporations) in the majority of tested companies that create a challenge of board independence because of the duality of the head of directors and executive manager position. Besides the lack of disclosure about non-financial information than financial information, such as disclosure on board members and top executives' compensations and salaries and the balance between executives and non-executive members in board composition, also there was no outstanding disclosure about non-audit fees and auditor's rotation.

From another perspective, there is no doubt that industry regulations can approve the steps forward adopting the best practices of sound governance; at the industry level (Figure 5) the Personal and household products sector reaches the highest level of compliance at .766 which classed into the second group and followed with Industrial, goods, and services and automobiles sector classified into the fair area. But, chemicals, food, and beverage industries which supposed to face a wide range of risks and well-organized with environmental and social regulations have partially attained the best practices of governance provisions with a compliance rate equal to .729 and .658 respectively.

As seen from the above results, Firm Policies and Procedures attribute is the least priority in the practice among the tested sample, where all firms were not passed in adopting the firm system guidelines; $50 \%$ of corporations are classed in group three and the rest are classified into group four. Despite, disclosure \& transparency provision was top-ranked among other provisions; Industrial, goods, service and automobiles and Basic resources sectors were accomplished a high degree of compliance. On the other hand, Construction and materials, Personal and household products and Food and beverage industries were almost committing the requirements of disclosure \& transparency in annual reports, governance filings, and websites.

All in all, the governance ratings are sensitive to the applied methodology. Particularly, a well-known approach in quantifying CG, i.e., equally weights, is underestimated the index findings then it will directly affect all aspects of governance endogeneity with firm performance/value this finding is consistent with the findings of Al-Shiab, (2003) and Nerantzidis (2016). For this reason, the researchers recommended that further studies have to carry out to test the impact of weights and equally weights on firms' performance and value for fulfilling the reliability of the index. 


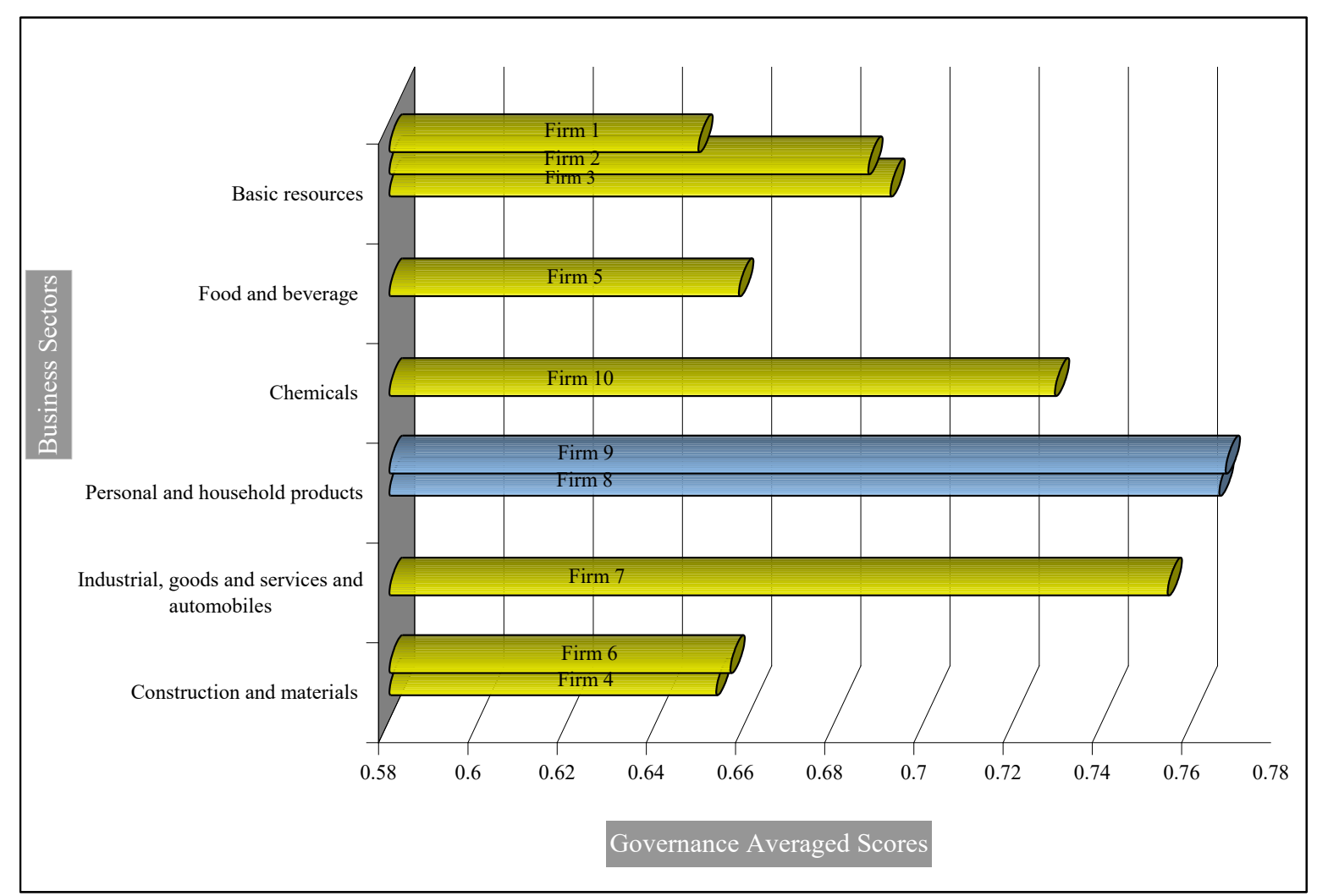

Figure 5. Compliance Rate at the Industry Level

\section{Conclusion}

The main point of this study is to adopt an information system view, Experts' method and statistical analysis to construct a valid Corporate Governance Index (CGI); it intends to develop a new methodology to overcome the shortcomings in the previous construction methodologies, with a concern of benchmarking listed companies' governance practices with local and international corporate governance guidelines. And ranking the tested companies and analyzing the internal and external triggers of governance compliance on firm and industry level.

Multi-methodologies have been used to develop a reliable quantitative index; (1) reviewing the governance literature for identifying the methodological gap in developing a governance assessment model by academics and institutions. and (2) Information system view is used to build a quantitative index in three main stages; output design from stakeholders' view; database design through using the principal component analysis to extract the relevant index measures and applying the modified Delphi technique for assigning the relative significance of each component; process design by adopting the electronic platform to compute and issue the index results.

The current study empirically concluded that board committees, disclosure and transparency, firm policies and rules, auditing and internal control and board of directors' independence and 
responsibilities are the main corners of the governance assessment index divided into 35 sub measures, meanwhile, disclosure and transparency are pivotal in the assessment process which has the heights priority with relative weight equal to $26 \%$.

The findings also suggested that the governance ratings are oversensitive to the quantification methodology. Particularly, an equal weighting approach is underestimated the index results then it will directly affect all aspects of governance endogeneity problems. For this reason, the researchers recommended that further studies have to carry out to test the impact of weights and equally weights on firms' performance and value for fulfilling the reliability of the index.

Furthermore, the researchers recommend that governance is not except for companies' management itself, because the firms' industry can play a fetal role in adopting the best practices of corporate governance by reforms in governance regulations and organizational law. So, the firms' environment should be governed and increasing the awareness about the role of the general assembly, board of directors and stakeholders in monitoring companies by conducting governance workshops regarding board incentives, related party transactions, investors' relations and how to report on the governance practices for each company concerning the "comply or explain" rule.

The practical implications of this paper are important for governance guidelines setters, policymakers, and stakeholders. For the G setters, policymakers, it underlines the necessity to harmonize between industries' regulations and governance code and revise the priority of the "comply or explain" approach in practice. In order to help firms and professional institutions put their action plans for governance enrichment, active participation of all parties and international affordability. For companies, the researchers recommend the importance of enhancing the role of the board of directors' committees, transparency \& disclosure on governance practices and explanations for non-compliance in annual reports or governance reports. For CGI users, the research highlights that ratings' users should be more precarious and concerned about the base of the assessing models. Finally, for academics, it boosts their knowledge in terms of methodological issues relating to governance assessment.

On the other hand, the current study has a number of limitations. First, the methods are used in this study; the Delphi technique has some critics, it is possible that a different set of participants would provide different results. Second, the benchmark of the CGI might present a limitation, as the Egyptian $\mathrm{G}$ code changes continuously whose affects the reliability of the index. Regarding future research, we think it would be mainly notable to involve more than one Experts' method regarding weights estimations to and enhance the reliability of results of the index; such as the Delphi model compared to the Analytic Hierarchy Process (AHP).

Also, it is important to keep on investigating the governance ratings in a large sample of companies and countries, in particular, those with emerging markets. The inclusion of cross-countries analysis will contribute significantly to the extension of the existing research on the relationship between corporate governance ratings and other firms' aspects such as market, operational or financial performance and firm value. Furthermore, investigating the effects of COVID 19 Pandemic on corporate governance Guidelines and 
ratings all over the world.

\section{Acknowledgements}

I would like to thank Prof. Samir R. Helal and Prof. Ahmad A. Abu-Musa for their supervision and comments, since this paper draws on data collected from my $\mathrm{PhD}$ thesis. I am also very grateful to all experts and participants in PCA exploratory study and involved in Delphi rounds for their recommendations and comments.

\section{References}

Abdi \& Williams (2010). Principal Component Analysis. WIREs Computational Statistics, 2, 433-459. https://doi.org/10.1002/wics.101

Abdullah, A., \& Page, M. (2009). Corporate Governance and Corporate Performance: UK FTSE 350 Companies. The Institute of Chartered Accountants of Scotland (C) 2009, Edinburgh, 1-132. https://doi.org/10.1016/j.bar.2010.01.003

Aggarwal, R., \& Williamson, R. (2007). Did New Regulations Target the Relevant Corporate Governance Attributes? Retrieved 24 June, 2017 from http://ssrn.com/abstract=859264

Agyemang, O. S., Gbettey, C., Gatsi, J., \& Acquah, I. S. K. (2019). Country-level corporate governance and foreign direct investment in Africa. Corporate Governance, 19(5), 1133-1152. https://doi.org/10.1108/CG-07-2018-0259

Al-Shiab, M. (2003). Financial consequences of IAS Adoption: The case of Jordan. Unpublished PHD thesis, University of New Castle Upon Tyne.

Ammann, M., Oesch, D., \& Schmid, M. M. (2009). Corporate Governance and Firm Value: International Evidence. Journal of Empirical Finance, 18(1), 36-55. https://doi.org/10.1016/j.jempfin.2010.10.003

Anderson, T. (1974). An Introduction to Multivariate Statistical Analysis. John Wiley, New York. USA.

Arcot, S., \& Bruno, V. (2005). One Size Doesn't Fit All, After All: Evidence from Corporate Governance. Retrieved from http://ssrn.com/abstract $=887947$

Arjoon, S. (2006). Striking a Balance between Rules and Principles-based Approaches for Effective Governance: A Risks-based Approach. Journal of Business Ethics, 68(53), 82. https://doi.org/10.1007/s10551-006-9040-6

Arndt, C., \& Oman, C. (2006). Uses and Abuses of Governance Indicators. Development Center Studies, OECD.

Bhagat, S., Bolton, B., \& Romano, R. (2008). The Promise and Peril of Corporate Governance Indices. Columbia Law Review, 108(8), 1803-1882. 
Baldacchino, B., Baldacchino, J., Bezzina, F., \& Tipurić, D. (2015). Assessing the Applicability of a Corporate Governance Index in Maltese Listed Entities. International Journal of Transitions and Innovation Systems, 4(1-2), 43-64. https://doi.org/10.1504/IJTIS.2015.074643

Balling, M., Holm, C., \& Poulsen, T. (2005). Corporate Governance Ratings as a Means to Reduce Asymmetric Information. Retrieved from http://research.mbs.ac.uk/accounting-finance/portals/0/docs/2007

Bebchuk, L., Cohen, A., \& Ferrell, A. (2008). What Matters in Corporate Governance? The Review of Financial Studies (RFS), Oxford University Press, 1-45.

Beiner, S., Drobetz, W., Schmid, M., \& Zimmermann, H. (2006). An Integrated Framework of Corporate Governance and Firm Valuation. European Financial Management, 12(2), 249-283. https://doi.org/10.1111/j.1354-7798.2006.00318.x

Black, B., Gledson, A., Khanna, V., Kim, W., \& Yurtoglu, B. (2017). Corporate Governance Indices and Construct Validity. Corporate Governance: An International Review, 25(6), 397-410. https://doi.org/10.1111/corg.12215

Brown, D., \& Caylor, M. L. (2006). Corporate governance and firm valuation. Journal of Accounting and Public Policy, 25(4), 409-434. https://doi.org/10.1016/j.jaccpubpol.2006.05.005

Bujaki, M., \& McConomy (2002). Corporate Governance: Factors Influencing Voluntary Disclosure by Publicly Traded Canadian Firms. Canadian Accounting Perspectives (CPA), 1(2), 105-139. https://doi.org/10.1506/9FN9-ECC9-7GL7-25NT

Cheung, Y., Connelly, J., Jiang, P., \& Limpaphayom, P. (2011). Does Corporate Governance Predict Future Performance? Evidence from Hong Kong? Financial Management, 40(1), 159-197. https://doi.org/10.1111/j.1755-053X.2010.01138.x

Clacher, I., Doriye, E., \& Hillier, D. (2008). Does Corporate Governance Matter? New Evidence from the United Kingdom? Retrieved from http://ssrn.com/abstract=1293188

Coles, j., Daniel, N. D., \& Naveen, L. (2008). Boards: Does one size fit all? Journal of Financial Economics, 87, 329-356. https://doi.org/10.1016/j.jfineco.2006.08.008

Credit Lyonnais Securities Asia (CLSA) (2001). Corporate Governance in Emerging Markets: CG Watch Report; Saints\& Sinners: Who's Got Religion? Hong Kong: CLSA Research. Retrieved from http://www.clsa.com/

Cremers, M., \& Nair, V. (2005). Governance mechanisms and equity prices. Journal of Finance, 60, 2859-2894. https://doi.org/10.1111/j.1540-6261.2005.00819.x

Crisóstomo, V., \& de Freitas Brandão, I. (2019). The Ultimate Controlling Owner and Corporate Governance in Brazil. Corporate Governance, 19(1), 120-140. https://doi.org/10.1108/CG-01-2018-0043

Daines, R. M., Gow, I. D., \& Larcker, D. F. (2009). Rating the ratings: how good are 
commercial governance ratings? Rock Center for Corporate Governance at Stanford University Working Paper Series No. 1, 98(3), 1-74. https://doi.org/10.1016/j.jfineco.2010.06.005

Donker H., \& Zahir, S. (2008). Towards an impartial and effective corporate governance rating system. Emerald Group Publishing Limited. J. Corporate Governance, 8(1), 83-93. https://doi.org/10.1108/14720700810853428

Drobetz, W., Schillhofer, A., \& Zimmermann, H. (2004). Corporate Governance and Expected Stock Returns: Evidence from Germany. European Financial Management, 10(2), 267-293. https://doi.org/10.1111/j.1354-7798.2004.00250.x

Egyptian Institute of Directors (2016). Guide to Corporate Governance Regulations and Standards in Egypt. Egyptian IOD, Egyptian Financial Supervisory Authority, Arab Republic of Egypt. (In Arabic)

Fathi, J. (2013). Corporate Governance System and Quality of Financial Information. Mediterranean Journal of Social Sciences: Published by MCSER-CEMAS-Sapienza University of Rome, 4(2), 129-142. https://doi.org/10.5901/mjss.2013.v4n2p129

Field, A. (2009). Discovering Statistics Using SPSS (3rd ed.). Published by: SAGE Publications Ltd., UK \& USA.

Financial Supervisory Commission (2018). Corporate Governance Roadmap (2018 2020): Taiwan.

Florou, A., \& Galarniotis, A. (2007). Benchmarking Greek corporate governance against different standards. Corporate Governance: an International Review, 15(5), 979-998. https://doi.org/10.1111/j.1467-8683.2007.00614.x

FTSE (2005). FTSE ISS Corporate Governance Rating and Index Series- Measuring the Impact of Corporate Governance on Global Portfolios. FTSE ISS CGI SERIES RESEARCH REPORT.

Gherghina S. C., Vintilă, G., \& Ţibulcă, I. L. (2014). A Study on the Relationship between Corporate Governance Ratings and Company Value: Empirical Evidence for S\&P 100 Companies. International Journal of Economics and Finance, 6(7), 242-253. https://doi.org/10.5539/ijef.v6n7p242

Goergen, M., Mallin, C., \& Mitleton-Kelly, E., Al-Hawamdeh, A., \& Chiu, H. (2010). Corporate Governance and Complexity Theory. Published by: Edward Elgar Publishing Limited, USA. https://doi.org/10.4337/9781849808002

Gompers, A., Ishii, A., \& Metrick, A. (2003). Corporate governance and equity prices. Quarterly Journal of Economics, 118(1), 107-155. https://doi.org/10.1162/00335530360535162

Gordon, T. J. (1994). The Delphi method, AC/UNU millennium project, future research methodology. $\quad$ Retrieved $21 \quad$ November, 2017 from 
www.millennium-project.org/millennium/RTD-method

Gordon, I. M., Hrazdil, K., \& Shapiro, D. (2012). Corporate Governance in Publicly Traded Small Firms: A Study of Canadian Venture Exchange Companies. Business Horizons, 55, 583-591. https://doi.org/10.1016/j.bushor.2012.07.005

Grimminger, A., \& Benedetta, B. Di. (2013). Raising the Bar on Corporate Governance: A Study of Eight Stock Exchange Indices. A copublication of the World Bank and the International Finance Corporation (IFC). The International Bank for Reconstruction and Development/The World Bank, 1-43.

Habibi, A., \& Sarafrazi, A. (2014). Delphi Technique Theoretical Framework in Qualitative Research. The International of Engineering and Science (IHES), 3(4), 8-13.

Hair, J., Black, W., Babin, B., \& Anderson, R. (2010). Multivariate Data Analysis (7th ed.). Pearson Prentice Hall.

Haldar, A., \& Rao, S. (2013). Corporate Governance Index for Listed Indian Companies. Retrieved from http://www.researchgate.net/publication/2560604 97

Herbert (2018). Retrieved from http://www.accountingweb.co.uk

Higgs, D. (2003). Review of the Role and Effectiveness of Non-Executive Directors. Retrieved from http://www.dti.gov.uk/cld/

Hill, G. W. (1982). Group versus individual performance: are N+1 heads better than one? Psychological Bulletin, 91(3), 517-539.

Hitz, J.-M., \& Lehmann, N. (2015). Market-based evidence on the usefulness of corporate governance ratings. Retrieved from http://ssrn.com/abstract=2042019, 1-49.

Holm, C., Balling, M., \& Poulsen, T. (2014). Corporate Governance Ratings as a Means to Reduce Asymmetric Information. Cogent Economics \& Finance, 2(1, 919235), 1-16.

Hooper, D. (2012). Exploratory Factor Analysis. Books/Book Chapters. Dublin Institute of Technology. Retrieved from http://arrow.dit.ie/buschmanbk

Kao, M., Hodgkinson, L., \& Jaafar, A, (2019). Ownership structure, board of directors and firm performance: evidence from Taiwan. Corporate Governance, 19(1), 189-216.

Keeney, S., Hasson, F., \& McKenna, H. (2001). A Critical Review of the Delphi Technique as a Research Methodology for Nursing. Journal of Advanced Nursing, 38(2), 195-200.

Khanchel, I. (2007). Corporate Governance: Measurement and Determinants Analysis. Managerial Auditing, 22(8), 740-778.

Kusi, B., Gyeke-Dako, A., Agbloyor, E., \& Darku, A. (2018). Does corporate governance structures promote shareholders or stakeholders value maximization? Evidence from African banks. Corporate Governance, 18(2), 270-288.

International Finance Corporation (IFC) (2014). Corporate Governance Scorecards: 
Assessing and Promoting the Implementation of Codes of Corporate Governance. Supplement to Toolkit 2: Developing Corporate Governance Codes of Best Practice. International Finance Corporation, World Bank Group, Washington.

Indonesian Institute for Corporate Governance (IICG, 2006). Laporan Corporate Governance $\begin{array}{lllll}\text { Perception Index 2005. Retrieved } 3 & \text { May, } & 2017\end{array}$ https://doslide.net/philosophy-of-money.html?utm_source=laporan-cgpi-2005/

Institute of Directors (IoD) (2016). The 2016 Good Governance Report: The great governance debate continued. United Kingdom.

Institutional Shareholder Services Inc. ISS Governance QuickScore (2013). Retrieved from http://issgovernance.com/files/ISSGovernanceQuickScoreTechDoc.pdf

International Finance Corporation (IFC) (2014). Corporate Governance Scorecards: Assessing and Promoting the Implementation of Codes of Corporate Governance. Supplement to Toolkit 2: Developing Corporate Governance Codes of Best Practice, International Finance Corporation, World Bank Group, Washington.

Japan Corporate Governance Index Research Group (JCGR) (2006). The 5th Corporate Governance Survey.

Klapper, L. F., \& Love, I. (2002). Corporate Governance, Investor Protection, and Performance in Emerging Markets", Policy Research Working Papers. The World Bank, 1-38, Development Research Group, Washington. Retrieved from http://econ.worldbank.org

Landeta, J. (2006). Current validity of the Delphi method in social sciences. Technological Forecasting and Social Change, 73(5), 467-482.

La Porta, R., Lopez-de-Silanes, F., Shleifer, A., \& Vishny, R. (1998). Law and Finance. The Journal of Political Economy, 106(6), 1113-1155.

Larcker, D., Richardson, S., \& Tune, I. (2007). Corporate Governance, Accounting Outcomes, and Organizational Performance. The Accounting Review, 82, 963-1008.

Linden, P., \& Matolcsy, Z. (2004). Corporate Governance Systems: What Do They Tell Us? Australian Accounting Review, 14(1), 9-16.

Mallin (2003). The Relationship between Corporate Governance, Transparency and Financial Disclosure. Corporate Governance: An International Review, 10(4).

Martynova, M., \& Renneboog, L. (2010). A Corporate Governance Index: Convergence and Diversity of National Corporate Governance Regulations. Center Q, Tilburg University, ISSN 0924-7815. Retrieved from http://ssrn.com/abstract $=1557627$

McCulloch (2018). Carillion enters into liquidation. Retrieved from http://www.insider.Co.UK

Mohanty, P. (2003). Institutional Investors and Corporate Governance in India. National 
Stock Exchange if India Research Initiative Paper, (15). Retrieved from $\mathrm{http}: / /$ www.ssrn.com/abstract $=353820$

Moody's Investors Service (2003). Moody's Rating Methodology. U.S. and Canadian Corporate Governance Assessment, 1-8.

Mostafa, H. (2012). A disclosure index to measure the extent of corporate governance reporting by UAE listed corporations. Journal of Financial Reporting \& Accounting, 4-33.

Munisi, G., \& Randøy, T. (2013). Corporate governance and company performance across Sub-Saharan African countries. J. Economics and Business, 70, 92-110.

Nerantzidis, M. (2018). The role of weighting in corporate governance ratings. Journal of Management and Governance, 22(3), 589-628.

Nerantzidis, M. (2016). A multi-methodology on Building a Corporate Governance Index from the Perspectives of Academics and Practitioners for Firms in Greece. J. Corporate Governance, 16(2), 295-329. https://doi.org/10.1108/CG-08-2015-0107

Nworie, J. (2011). Using the Delphi Technique in Educational Technology Research. TechTrends, 55(5), 24-30.

OECD (2015). G20/OECD Principles of Corporate Governance OECD. Report to G20 Finance Ministers and Central Bank Governors, 1-62.

Pletz S., \& Upson, J. (2019). The normative evolution of corporate governance in the UK: an empirical analysis (1995-2014). Corporate Governance, 19(5), 1015-1041. https://doi.org/10.1108/CG-07-2018-0239

Pratley (2018). Deeper scandal at Carillion was Pension Regulator's inaction. Retrieved from http://www.theguardian.com

Price, R., Roman, F., \& Rountree, B. (2011). The Impact of Governance Reform on Performance and Transparency. Journal of Financial Economics, 99(1), 76-96. https://doi.org/10.1016/j.jfineco.2010.08.005

Romney, M., \& Steinbart, P. (2015). Accounting Information Systems (13th ed.). C Pearson, USA.

Rühmkorf, A., Spindler, F., \& Samanta, N. (2019). Evolution of German corporate governance (1995-2014): an empirical analysis. Corporate Governance, 19(5), 1042-1062. https://doi.org/10.1108/CG-07-2018-0251

Rutherford and Costello (1999). Measuring Corporate Governance in Russia. Brunswick UBS Warburg Corporation: Russia.

Rahn, M. (2017). Factor Analysis: A Short Introduction, Part 4-How Many Factors Should I Find. Retrieved 25 December, 2017 from http://theanalysisfactor.com

Sabbaghi, O. (2016). Corporate governance in China: a review. Corporate Governance, 16(5), 
866-882. https://doi.org/10.1108/CG-12-2015-0162

Schnyder, G. (2012). MeasuringCorporate governance: Lessons from the Bundles Approach. Working paper of the CBR research program on Corporate Governance. https://doi.org/10.2139/ssrn.2220616

Schwab, K., \& Sala-i-Martin, X. (2014). The Global Competitiveness Report 2014-2015. World Economic Forum, Geneva.

Shabbir, A., \& Badgett, C. C. (2005). The UK Code of Corporate Governance: Link between Compliance and Firm Performance. ICMA Center Discussion Papers in Finance DP2005-17, International Capital Market Association. Retrieved from http://papers.ssrn.com/papers.cfm?abstract $=93431$

Shan, H., \& Kalaian, S. (2009). Which is the Best Parametric Statistical Method for Analyzing Delphi Data? Journal of Modern Applied Studies, 8(1), 226-232. https://doi.org/10.22237/jmasm/1241137140

Skulmoski, G. J., Hartman, F. T., \& Krahn, J. (2007). The Delphi method for graduate research. Journal of Information Technology Education, 6, 1-21. https://doi.org/10.28945/199

Standard \& Poor's (2002). Standard \& Poor's Corporate Governance Scores: Criteria, Methodology and Definitions. McGraw-Hill Companies Inc., New York, U.S.A, 1-16.

(2002). Transparency and Disclosure: Overview of Methodology and Study Results-United States. S\&P's, USA.

and Hawkamah (2011). S\&P/Hawkamah ESG Pan Arab Index Methodology. McGraw-Hill Companies, Inc. New York, USA.

Strenger, C. (2004). The Corporate Governance Scorecard: A Tool for the Improvement of Corporate Governance. Blackwell Publishing Ltd, 12(1), 11-15. https://doi.org/10.1111/j.1467-8683.2004.00339.x

Tariq, Y., \& Abbas, Z. (2013). Compliance and Multidimensional Firm Performance: Evaluating the Efficiency of Rule-Based Code of Corporate Governance. Economic Modelling, 35, 565-575. https://doi.org/10.1016/j.econmod.2013.08.015

Tsipouri, L., \& Xanthakis, M. (2004). Can Corporate Governance Be Rated? Ideas Based on the Greek Experience. Corporate Governance: An International Review, 12(1), 16-28. https://doi.org/10.1111/j.1467-8683.2004.00340.x

United Nations Conference on Trade and Development (UNCTAD) (2006). Guidance on Good Practices in Corporate Governance Disclosure. United Nations, New York and Geneva.

The World Bank (2009). Report on The Observance of Standards and Codes (ROSC) A Corporate Governance Country Assessment for The Arab Republic of Egypt, 159. The International Bank for Reconstruction and Development / The World Bank. 


\section{APPENDIX 1}

Corporate governance attributes and sub-measures as an input of Exploratory Factor Analysis

\begin{tabular}{|c|c|c|c|}
\hline Corporate Governance Variables & $\begin{array}{l}\text { EG. } \\
\text { code }\end{array}$ & OECD & ISAR \\
\hline \multicolumn{4}{|l|}{ Shareholders Rights } \\
\hline $\begin{array}{l}\text { A timetable of general assembly should be well known to the public with } \\
\text { enough time and disclosed on the firm's website. }\end{array}$ & $\checkmark$ & $\checkmark$ & \\
\hline $\begin{array}{l}\text { Shareholders have the rights to access, vote and participate in general assembly } \\
\text { by post or proxy. }\end{array}$ & $\checkmark$ & $\checkmark$ & $\checkmark$ \\
\hline Equality of disclosure to maintain minority shareholders rights. & & $\checkmark$ & $\checkmark$ \\
\hline $\begin{array}{l}\text { Shareholders are incorporated in preparing the agenda of the shareholders } \\
\text { meeting. }\end{array}$ & $\checkmark$ & $\checkmark$ & $\checkmark$ \\
\hline Cumulative voting vs. majority voting in taking decisions. & $\checkmark$ & $\checkmark$ & \\
\hline \multicolumn{4}{|l|}{ Board of Directors (Responsibilities, Independence, Structure) } \\
\hline Board comprises at least two independent members with experience. & $\checkmark$ & $\checkmark$ & $\checkmark$ \\
\hline $\begin{array}{l}\text { Board independence should be maintained through disclosing direct or indirect } \\
\text { interests in the company. }\end{array}$ & $\checkmark$ & & $\checkmark$ \\
\hline $\begin{array}{l}\text { CEO duality is not supported, if not a firm should disclose in annual reports and } \\
\text { websites. }\end{array}$ & $\checkmark$ & $\checkmark$ & \\
\hline $\begin{array}{l}\text { The board should be comprised of majority of non-executive and expertise in the } \\
\text { company's activities. }\end{array}$ & $\checkmark$ & $\checkmark$ & $\checkmark$ \\
\hline $\begin{array}{l}\text { Training of board members and employees including corporate governance } \\
\text { culture. }\end{array}$ & $\checkmark$ & & $\checkmark$ \\
\hline $\begin{array}{l}\text { General oversight on information disclosure to maintain the integrity of annual } \\
\text { reports. }\end{array}$ & $\checkmark$ & $\checkmark$ & \\
\hline Disclosure on the board of directors nominating period. & $\checkmark$ & $\checkmark$ & \\
\hline $\begin{array}{l}\text { At least one of the minority shareholders are represented in the board of } \\
\text { directors. }\end{array}$ & $\checkmark$ & $\checkmark$ & \\
\hline $\begin{array}{l}\text { Self-evaluation of board and performance of members conducted by the head of } \\
\text { directors regularly. }\end{array}$ & $\checkmark$ & $\checkmark$ & $\checkmark$ \\
\hline Board meetings can be held using new technology. & $\checkmark$ & $\checkmark$ & \\
\hline Employees should be incorporated in board composition. & $\checkmark$ & $\checkmark$ & \\
\hline Shareholders are evaluating the board of directors in terms of its reports. & $\checkmark$ & $\checkmark$ & $\checkmark$ \\
\hline
\end{tabular}


Board Committees (rules \& functions)

Board committees comprise of at least three non-executive board members

Board committee meetings comprised of at least three months and would be correct at $50 \%$ of attendance or minimum level of construction

The Board of directors confirm the composition and responsibilities of the board committee

Audit committee; approved the decision of auditor appointment, and reviewing the audit plan, auditor's recommendations and firm responses.

Audit committee; approved the decision of selection, dismissal and financial terms of the head of internal control and internal audit.

Audit committee; Overseeing financial statements \& accounting policies before reporting to the board.

Governance committee; supervising firm's governance structure and preparing a report on firm compliance of $\mathrm{G}$ Code.

Governance committee; reviewing annual reports and board reports in terms of governance issues.

Compensation committee; compensating of the board, committee members and large executives depending on performance standards and confirms no conflicts with firms policies.

Compensation committee; Reviewing Disclosure relates to the benefits and compensations policy of the board, committee members and large executives during the year.

The nominating committee aims at reviewing the requirements of qualifications and skills needed in board members.

A nominating committee is accountable for the independence of non-executive and independent board members.

At least one of the audit committee members has financial and accounting expertise.

\section{Disclosure \& Transparency}

Annual reports should include financial and non-financial information

Disclosed information should have good characteristics of information quality; transparency, completeness, comparability, timeliness.

Firms' websites should be stimulating and updating regularly.

Disclosed information should be prepared using generally accepted accounting standards.

Annual reports have been audited by independent auditors.

Annual reports are presented in Arabic and English languages.

Disclosure on Equity Structure including voting rights.

Disclosure of accounting estimates and policies. 
Listed companies should disclose their board committee composition and the balance between executives and non-executives.

Disclosing on material risks and exist actions to fight them.

Disclosure on related party transactions

Disclosure on firm compliance of governance guidelines and its approach for such commitment.

\section{Audit \& Internal Control}

Functional reporting to the audit committee or board directly and administrative reporting to the Chief Executive Officer (CEO) to maintain internal audit independence.

Evaluating and reporting to the audit committee on the effectiveness of internal control.

The internal audit assesses the efficiency and the effectiveness of internal control and reporting to the audit committee about the results.

Auditors rotating after 5 years and do not reappointing before 3 years

The general assembly is appointing an external auditor or more depends upon the approval of the board and audit committee.

The audit committee should be approved the non-audit services provided by the firm's auditor to maintain the auditors' independence. And non-audit fees should be balanced with audit fees.

Auditors should realize the standards of proficiency, integrity, independence.

Auditors should due professional care and be independent in their work.

Firm Policies \& Procedures

Ensuring the firm's conducting a code of ethics, rules and policies.

Acquisitions of shares by firms' directors or employees must be disclosed and organized by firm rules.

Put general rules of performing and advocating the related party transactions with internal and external parties.

Assessing the acceptable level of risks and establish proxies to measure risks.

Analyzing, assessing and reporting the firm risks

Reviewing the reports of activity risks and tacking actions before reporting on the board.

Risk management reports to the board of directors, risk committee or audit committee if the risk committee does not exist.

Management is responsible for establishing effective procedures to attain accountability, responsibility and awareness toward firm values.

Each Firm ought to have a code of ethics involving organizational values, ethical issues.

Compliance management informs about unethical behaviors to trustworthy parties. 


\section{APPENDIX 2}

\section{Content analysis for the tested sample}

\begin{tabular}{|c|c|c|c|c|c|c|c|c|c|c|}
\hline board committees & \multicolumn{10}{|c|}{ scores } \\
\hline The general policy of board committees & F.1 & F.2 & F.3 & F.4 & F. 5 & F.5 & F.7 & F. 8 & F.9 & F.10 \\
\hline $\begin{array}{l}\text { 1. Board committees comprise of at least three } \\
\text { non-executive board members }\end{array}$ & 1 & 1 & 1 & 1 & 1 & 1 & 1 & 1 & 1 & 1 \\
\hline $\begin{array}{l}\text { 2. Board committee meetings comprised of at least three } \\
\text { months and would be correct at } 50 \% \text { of attendance or } \\
\text { minimum level of construction }\end{array}$ & 1 & 1 & 1 & 1 & 1 & 1 & 1 & 1 & 1 & 1 \\
\hline $\begin{array}{l}\text { 3. Board of directors confirm the composition and } \\
\text { responsibilities of the board committee }\end{array}$ & 1 & 1 & 0 & 0 & 0 & 1 & 0 & 1 & 1 & 0 \\
\hline $\begin{array}{l}\text { 4. Board should be comprised of the majority of } \\
\text { non-executive and expertise in the company's activities }\end{array}$ & 1 & 1 & 0 & 0 & 0 & 1 & 0 & 0 & 1 & 0 \\
\hline \multicolumn{11}{|l|}{ Audit committee responsibilities } \\
\hline $\begin{array}{l}\text { 5. Approved the decision of auditor appointment, and } \\
\text { reviewing the audit plan, auditor's recommendations and } \\
\text { firm responses. }\end{array}$ & 0 & 0 & 0 & 0 & 0 & 0 & 0 & 0 & 0 & 0 \\
\hline $\begin{array}{l}\text { 6. Approved the decision of selection, dismissal and } \\
\text { financial terms of the head of internal control and internal } \\
\text { audit. }\end{array}$ & 0 & 0 & 0 & 0 & 0 & 0 & 0 & 0 & 0 & 0 \\
\hline $\begin{array}{l}\text { 7. Overseeing financial statements \& accounting policies } \\
\text { before reporting to the board. }\end{array}$ & 1 & 1 & 1 & 1 & 1 & 1 & 1 & 0 & 1 & 0 \\
\hline \multicolumn{11}{|l|}{ Governance Committee Functions } \\
\hline $\begin{array}{l}\text { 8. Supervising firm's governance structure and preparing a } \\
\text { report on firm compliance with G Code. }\end{array}$ & 0 & 0 & 0 & 0 & 0 & 0 & 0 & 0 & 0 & 0 \\
\hline $\begin{array}{l}\text { 9. Reviewing annual reports and board reports in terms of } \\
\text { governance issues. }\end{array}$ & 0 & 0 & 0 & 0 & 0 & 0 & 0 & 0 & 0 & 0 \\
\hline $\begin{array}{l}\text { 10. Disclosing on material risks and exist actions to fight } \\
\text { them. }\end{array}$ & 0 & 1 & 1 & 1 & 1 & 0 & 1 & 0 & 1 & 0 \\
\hline \multicolumn{11}{|l|}{ Remunerations committee functions } \\
\hline $\begin{array}{l}\text { 11. Compensating of the board, committee members and } \\
\text { large executives depending on performance standards and } \\
\text { confirms no conflicts with firms policies. }\end{array}$ & 0 & 0 & 0 & 0 & 0 & 0 & 0 & 0 & 1 & 0 \\
\hline $\begin{array}{l}\text { 12. Reviewing Disclosure relates benefits and } \\
\text { compensations policy of the board, committee members } \\
\text { and large executives during the year. }\end{array}$ & 0 & 0 & 0 & 0 & 0 & 0 & 0 & 0 & 1 & 0 \\
\hline
\end{tabular}




\section{APPENDIX 3}

\section{Part of Companies' self-evaluation form}

\begin{tabular}{|c|c|c|c|c|c|c|c|c|c|c|c|}
\hline board committees & \multicolumn{11}{|c|}{ Evaluation scores } \\
\hline \multicolumn{12}{|l|}{ The general policy of board committees } \\
\hline $\begin{array}{l}\text { 1. Board committees comprise of at least three non-executive board } \\
\text { members }\end{array}$ & 0 & 1 & 2 & 3 & 4 & 5 & 6 & 7 & 8 & 9 & 10 \\
\hline $\begin{array}{l}\text { 2. Board committee meetings comprised of at least three months and } \\
\text { would be correct at } 50 \% \text { of attendance or minimum level of } \\
\text { construction }\end{array}$ & 0 & 1 & 2 & 3 & 4 & 5 & 6 & 7 & 8 & 9 & 10 \\
\hline $\begin{array}{l}\text { 3. Board of directors confirm the composition and responsibilities of } \\
\text { the board committee }\end{array}$ & 0 & 1 & 2 & 3 & 4 & 5 & 6 & 7 & 8 & 9 & 10 \\
\hline $\begin{array}{l}\text { 4. Board should be comprised of the majority of non-executive and } \\
\text { expertise in the company's activities }\end{array}$ & 0 & 1 & 2 & 3 & 4 & 5 & 6 & 7 & 8 & 9 & 10 \\
\hline \multicolumn{12}{|l|}{ Audit committee responsibilities } \\
\hline $\begin{array}{l}\text { 5. Approved the decision of auditor appointment, and reviewing the } \\
\text { audit plan, auditor's recommendations and firm responses. }\end{array}$ & 0 & 1 & 2 & 3 & 4 & 5 & 6 & 7 & 8 & 9 & 10 \\
\hline $\begin{array}{l}\text { 6. Approved the decision of selection, dismissal and financial terms of } \\
\text { the head of internal control and internal audit. }\end{array}$ & 0 & 1 & 2 & 3 & 4 & 5 & 6 & 7 & 8 & 9 & 10 \\
\hline $\begin{array}{l}\text { 7. Overseeing financial statements } \& \text { accounting policies before } \\
\text { reporting to the board. }\end{array}$ & 0 & 1 & 2 & 3 & 4 & 5 & 6 & 7 & 8 & 9 & 10 \\
\hline \multicolumn{12}{|l|}{ Governance Committee Functions } \\
\hline $\begin{array}{l}\text { 8. Supervising firm's governance structure and preparing a report on } \\
\text { firm compliance with G Code. }\end{array}$ & 0 & 1 & 2 & 3 & 4 & 5 & 6 & 7 & 8 & 9 & 10 \\
\hline $\begin{array}{l}\text { 9. Reviewing annual reports and board reports in terms of governance } \\
\text { issues. }\end{array}$ & 0 & 1 & 2 & 3 & 4 & 5 & 6 & 7 & 8 & 9 & 10 \\
\hline 10. Disclosing on material risks and exist actions to fight them. & 0 & 1 & 2 & 3 & 4 & 5 & 6 & 7 & 8 & 9 & 10 \\
\hline \multicolumn{12}{|l|}{ Remunerations committee functions } \\
\hline $\begin{array}{l}\text { 11. Compensating of the board, committee members and large } \\
\text { executives depending on performance standards and confirms no } \\
\text { conflicts with firms policies. }\end{array}$ & 0 & 1 & 2 & 3 & 4 & 5 & 6 & 7 & 8 & 9 & 10 \\
\hline $\begin{array}{l}\text { 12. Reviewing Disclosure relates to the benefits and compensations } \\
\text { policy of the board, committee members and large executives during } \\
\text { the year. }\end{array}$ & 0 & 1 & 2 & 3 & 4 & 5 & 6 & 7 & 8 & 9 & 10 \\
\hline
\end{tabular}




\section{Copyright Disclaimer}

Copyright for this article is retained by the author(s), with first publication rights granted to the journal.

This is an open-access article distributed under the terms and conditions of the Creative Commons Attribution license (http://creativecommons.org/licenses/by/3.0/). 